\title{
Effects of the Operating Nuclear Power Plant on Marine Ecology and Environment - A Case Study of Daya Bay in China
}

\author{
You-Shao Wang1,2 \\ ${ }^{1}$ Key Laboratory of Tropical Marine Environmental Dynamics, South China Sea Institute \\ of Oceanology, Chinese Academy of Sciences, \\ ${ }^{2}$ Marine Biology Research Station at Daya Bay, Chinese Academy of Sciences,
}

China

\section{Introduction}

Bays and estuaries are known to be biologically productive and strongly influenced by human activities (Burger, 2003; Sohma et al., 2001; Tagliani et al., 2003; Zhao, 2005). Coastal bays is the region of strong land-ocean interaction, and their ecological functions are more complicated and vulnerable to the influence by human activities and land-source pollution than the open ocean (Bodergat et al., 2003; Hansom 2001; Huang et al., 2003; Yung et al., 2001). With the increase of population and rapid economic development, littoral areas are facing many ecological problems. Eutrophication and environmental pollution obviously occurred in many coastal sea areas, especially in estuaries and coastal bays (Cloern, 1996; Turner and Rabalais, 1994; Yin et al., 2001). These have directly resulted in the ecological unbalance, the decrease of biodiversity and the rapid reduction of biological resources in estuaries and coastal bays. Coastal ecosystems and the study of marine biological resources and ecological environment have attracted worldwide attention (Buzzelli, 1998; Fisher, 1991; Huang et al., 1989, 2003; Sohma et al., 2001, Souter and Linden, 2000; Zhang et al., 2001; Yung et al, 2001). Many international programs and projects have been launched to address the problems confronting the world's coastal ecosystems and biological resources (YanezArancibia et al., 1999; Huang et al., 2003).

Tang et al (2003) applied AVHRR data to the study of thermal plume from power plant at Daya Bay. Satellite remote sensing can provide information on the distribution and seasonal variation of thermal plumes from nuclear power plants that discharge cooling waters to the coastal zone. Variation of phytoplankton biomass and primary production in the western part of Daya Bay during spring and summer has been reported (Song et al., 2004). Wang et al (2006) used multivariate statistical analysis to reveal the relation between water quality and phytoplankton characteristics in Daya Bay, China, from 1999 to 2002. Wu and Wang (2007) used chemometrics to evaluate anthropogenic effects in Daya Bay and found that increases in human activities alter the balance of nutrients in Chinese coastal waters, and that the human activities were the main factor to impact the ecological environment in Daya Bay.

Data collected from 12 marine monitoring stations in Daya Bay from 1982 to 2004 reveal a substantial change in the ecological environment of this region (Wang et al., 2006, 2008, 2011). The average N/P ratio increased from 1.377 in 1985 to 49.09 in 2004. Algal species 
changed from 159 species of 46 genera in 1982 to 126 species of 44 genera in 2004, and the nutrients and phytoplankton are good environmental indicators which can rapidly reflect the changing water quality in Daya Bay (Wang et al., 2006). Major zooplankton species went from 46 species in 1983 to 36 species in 2004 . The annual mean biomass of benthic animals was recorded at $123.10 \mathrm{~g} \mathrm{~m}^{2}$ in 1982 and $126.68 \mathrm{~g} \mathrm{~m}^{2}$ in 2004 . Mean biomass and species of benthic animals near nuclear power plants ranged from $317.9 \mathrm{~g} \mathrm{~m}^{2}$ in 1991 to $45.24 \mathrm{~g} \mathrm{~m}^{2}$ in 2004 and from 250 species in 1991 to 177 species in 2004 (Wang et al., 2008). The waste warm water from nuclear power plants was the main factor influencing the ecology and environment in western areas of Daya Bay, especially for benthos near the Nuclear Power Plants in Daya Bay (Wang et al., 2011). Daya Bay is a multi-type ecosystem mainly driven by human activities (Wang et al., 2008).

As a case study of Daya Bay in China in this chapter, it is summarized long-term changes of Daya Bay and analyzed to effect of the operating Nuclear Power Plant on marine ecology \& environment according to the monitoring and research data in Daya Bay obtained during 1982-2004 in China (Wang et al., 2006, 2008, 2011).

\section{Research area, materials and methods}

China is a large coastal nation located along the western Pacific Ocean with $18000 \mathrm{~km}$ of mainland coastline, along which there are many large and important bays (Fig.1). Daya Bay is a semi-enclosed bay. It is one of large and important gulfs along the southern coast of China. Daya Bay is located at $113^{\circ} 29^{\prime} 42^{\prime \prime}-114^{\circ} 49^{\prime} 42^{\prime \prime} \mathrm{E}$ and $23^{\circ} 31^{\prime} 12^{\prime \prime}-24^{\circ} 50^{\prime} 00^{\prime \prime} \mathrm{N}$ (Fig.1). It covers an area of $600 \mathrm{~km}^{2}$ with a width of about $15 \mathrm{~km}$ and a north-south length of about 30 $\mathrm{km}$, and about $60 \%$ of the area in the Bay is less than $10 \mathrm{~m}$ deep (Xu, 1989; Wang et al., 2006, 2008, 2011). Dapeng Cove (the investigated station 3 is in it), in the southwest portion of Daya Bay, is about $4.5 \mathrm{~km}(\mathrm{~N}-\mathrm{S})$ by $5 \mathrm{~km}(\mathrm{E}-\mathrm{W})$. Located in a subtropical region, Daya Bay's annual mean air temperature is $22^{\circ} \mathrm{C}$. The coldest months are January and February, with a monthly mean air temperature of $15^{\circ} \mathrm{C}$, and the hottest months are July and August, with a monthly mean air temperature of $28^{\circ} \mathrm{C}$. The minimum sea surface temperature occurs in winter $\left(15^{\circ} \mathrm{C}\right)$ and the maxima in summer and fall $\left(30^{\circ} \mathrm{C}\right)(\mathrm{Xu}, 1989$; Wang et al., 2006, 2008, 2011). No major rivers discharge into Daya Bay, and most of its water originates from the South China Sea. There are three small rivers (Nanchong River, Longqi River and Pengcheng River) that discharge into Dapeng Cove. The Pearl River is to west of Daya Bay which has a diverse subtropical habitats including coral reefs, mangroves, rocky and sandy shores, mudflats, etc. (Wang et al., 2008). The coral reefs and mangroves have special resource values and ecological benefits and are very important to the sustainable social and economical development in these subtropical coastal areas. Coral reefs and mangrove areas have important relationships to the regulation and optimization of the subtropical marine environments and have become the subject of much international attention in recent years (Mumby et al., 2004; Pearson, 2005).

Relatively few residents and industries along the cost of Daya Bay before 1980s, and there are about 239400 inhabitants living along the coast of Daya Bay at present (Fig.2). The population has nearly doubled during 1986-2002. Many factories had been built. The total industrial output value of the main towns along Daya Bay coast increased from 3.804 billion yuans of 1993 to 29.64 billion yuans of 2001(Wang et al., 2008). The total industrial output value of the main towns along the Daya Bay coast had increased 7.8 times between 1993 and 2001 (Fig.3). The Daya Bay Nuclear Power Plant (DNPP) (Fig.4) was the first nuclear power 

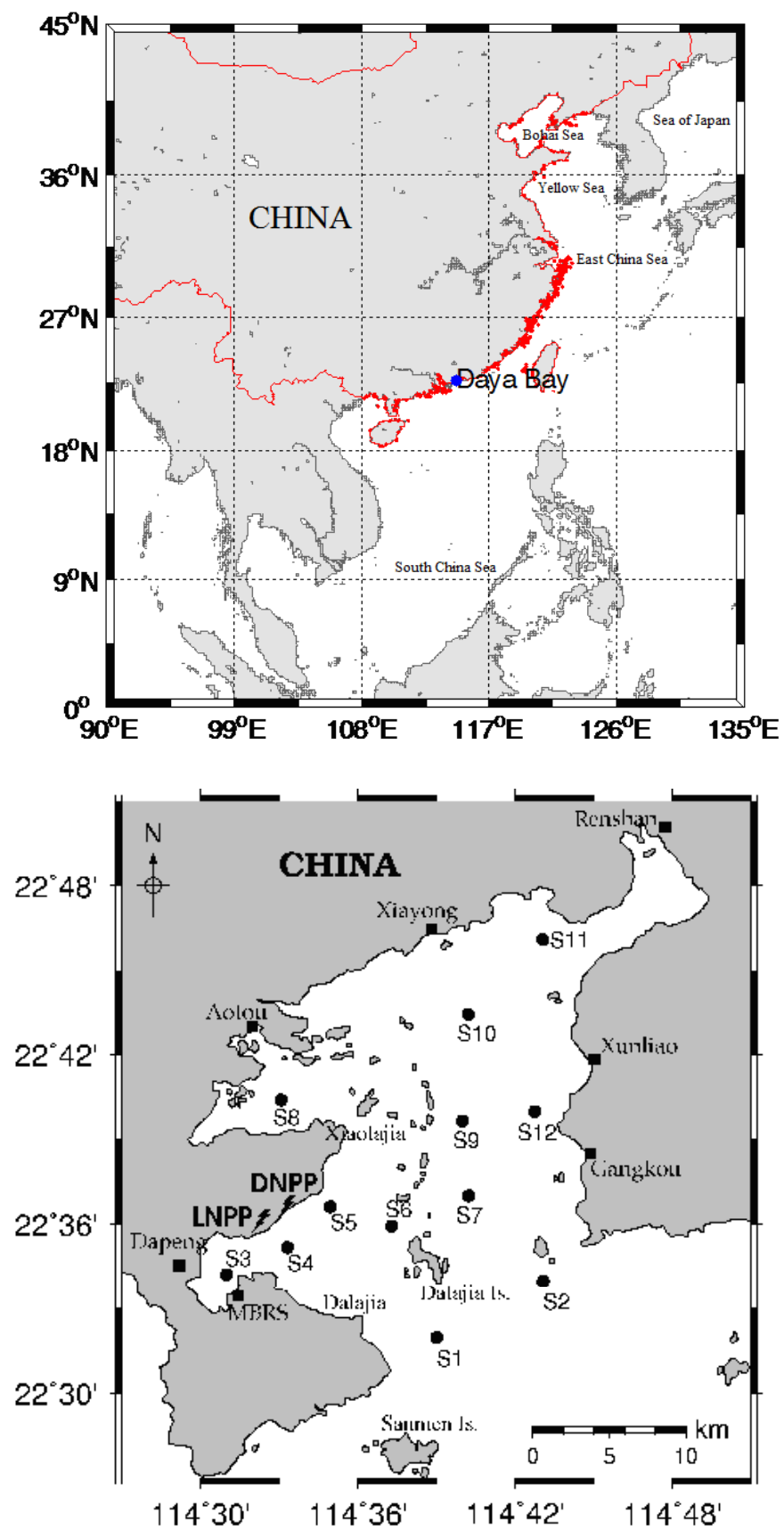

Fig. 1. Map for Daya Bay and its Locations of the 12 monitoring stations (Wang et al., 2006, 2008, 2011). 
plant and the largest foreign investment joint project in China since 1982 and marked the first step taken by China in the development of large-capacity commercial nuclear power units (Zang, 1993). The sea water from the Daya Bay Nuclear Power Plant is discharged in about $95 \mathrm{~m}^{3}$ second $^{-1}$ at $65^{\circ} \mathrm{C}$ since 1993, and the warm water is put into the south area of Daya Bay (Fig.4).

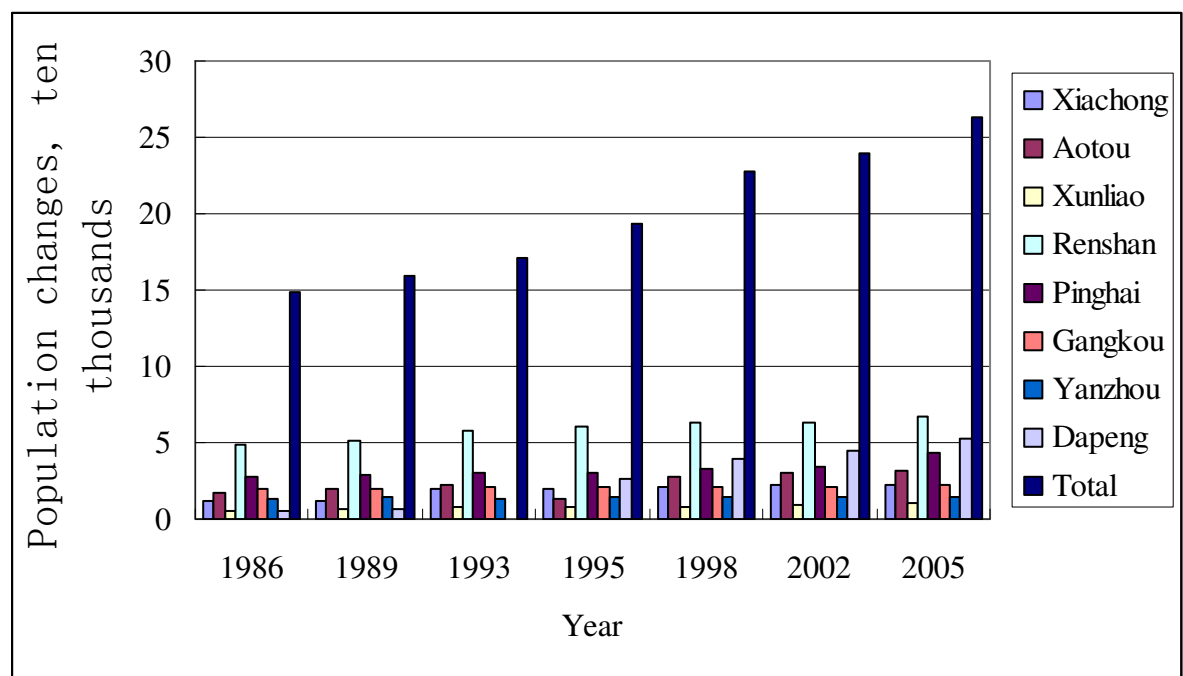

Fig. 2. Population changes of the main towns along the Daya Bay coast (unit: ten thousands).

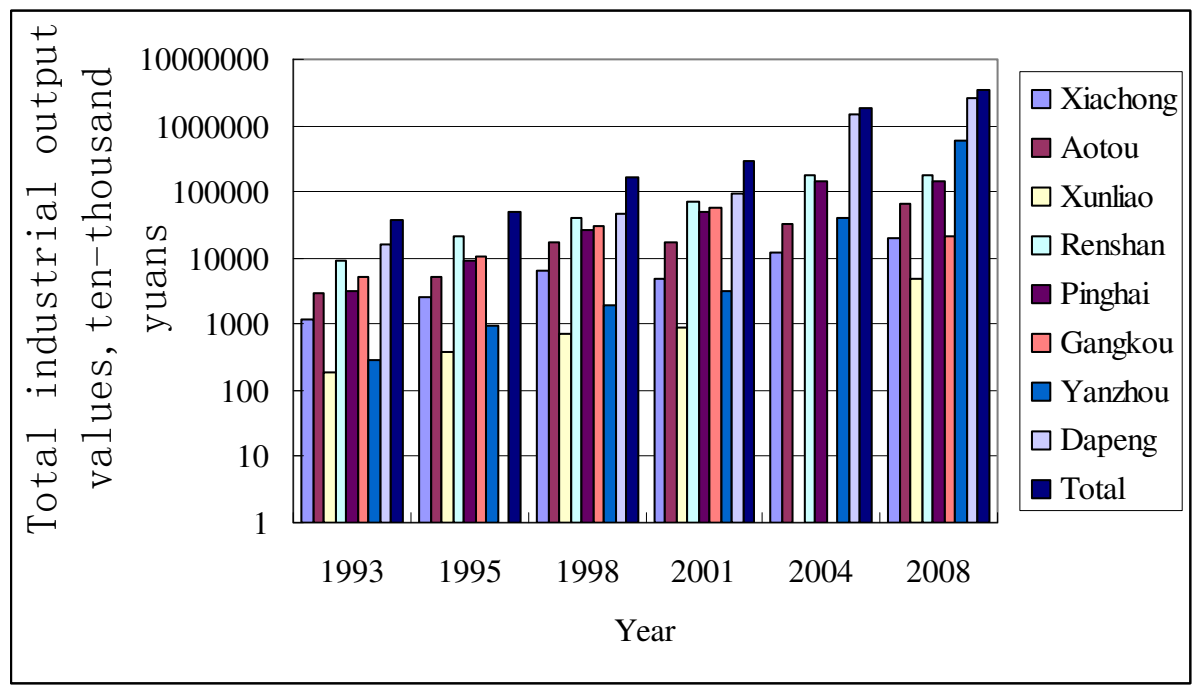

Fig. 3. Total industrial output values of the main towns along the Daya Bay coast in different year (unit: ten thousands yuans). 


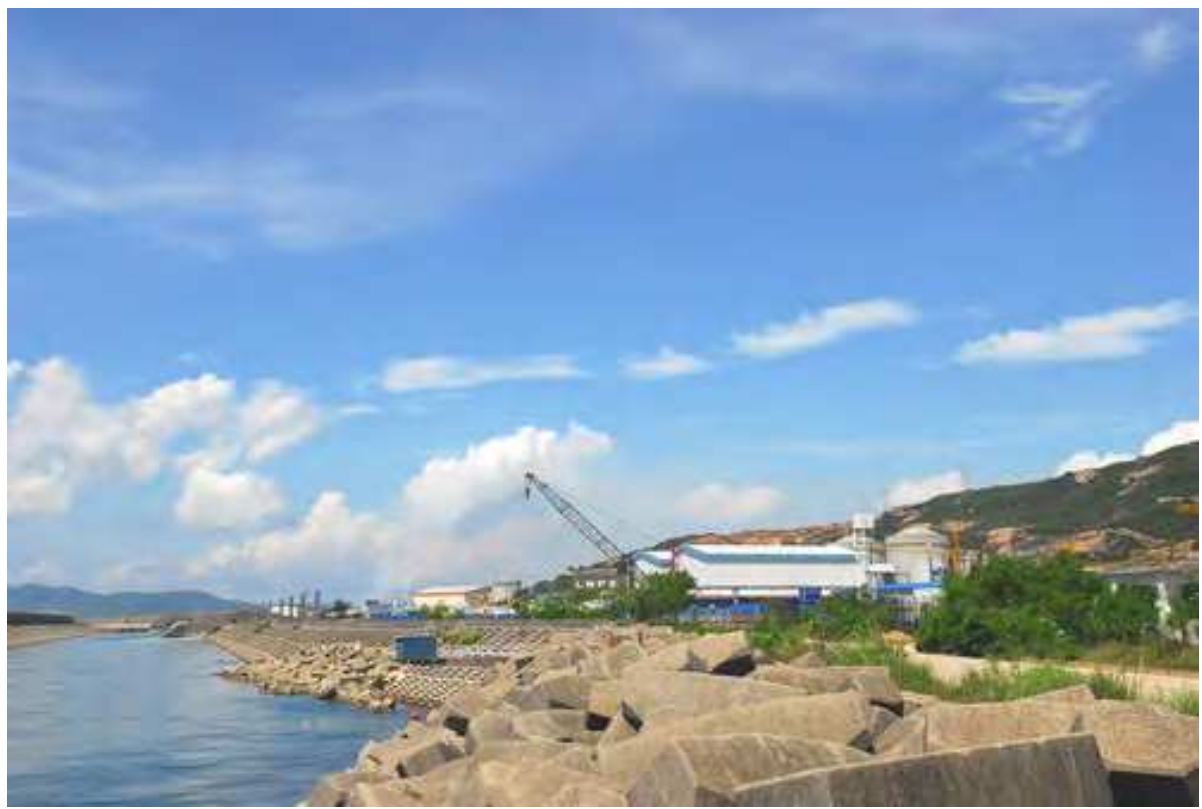

(1) Lingao phase I (From http:/ / www.google.com.hk/)

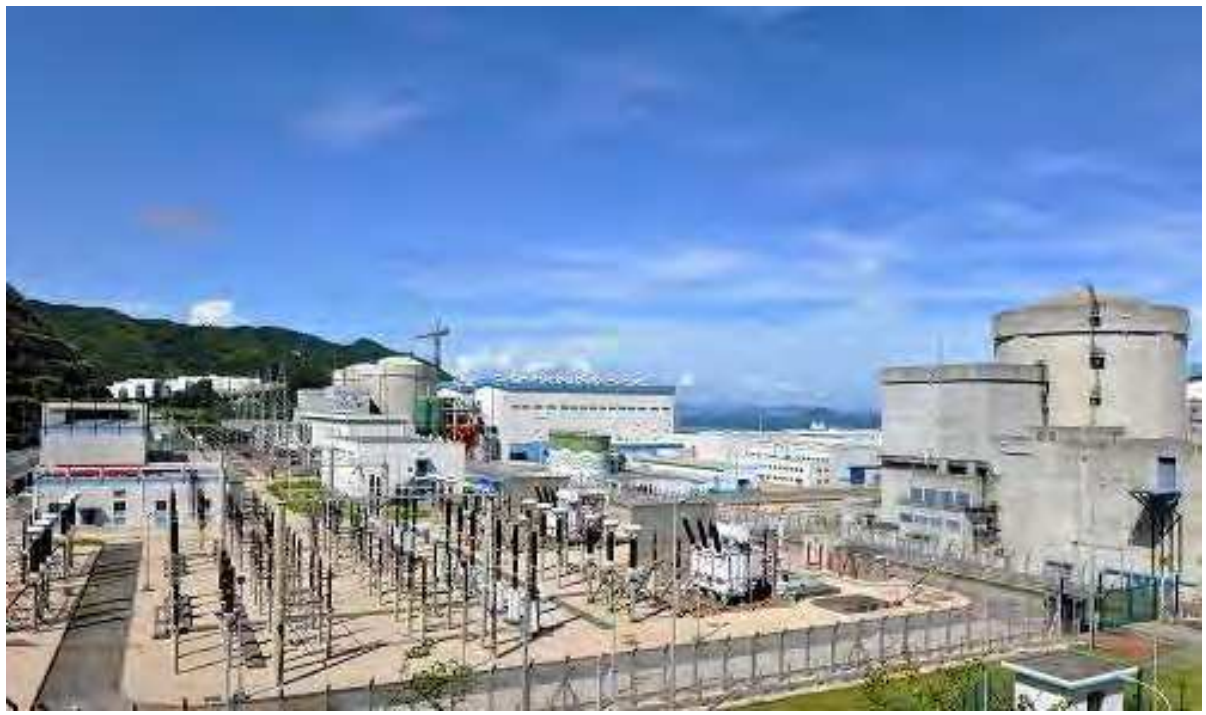

(2) Lingao phase II (From http:/ / www.google.com.hk/)

A: Lingao Nuclear Power Plant in China 


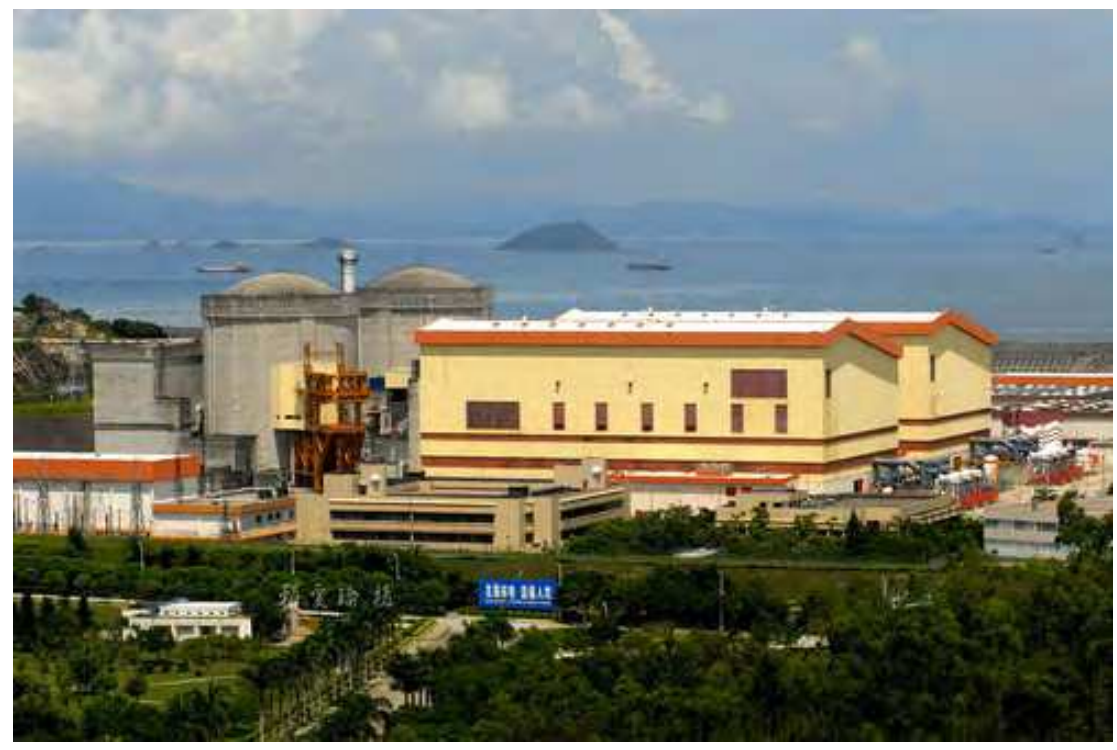

B: Daya Bay Nuclear Power Plant in China (From http://www.google.com.hk/)

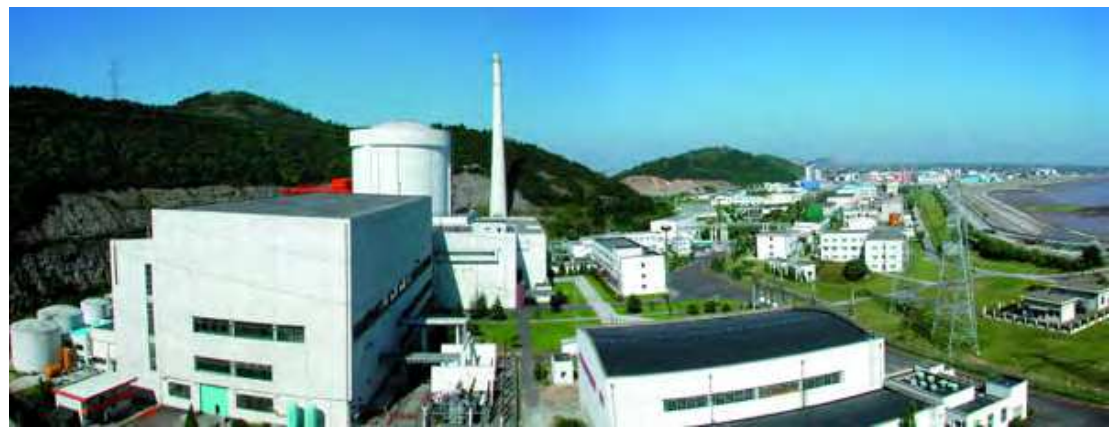

(1) Qinshan phase I (From http:/ / www.google.com.hk /) 
Effects of the Operating Nuclear Power Plant

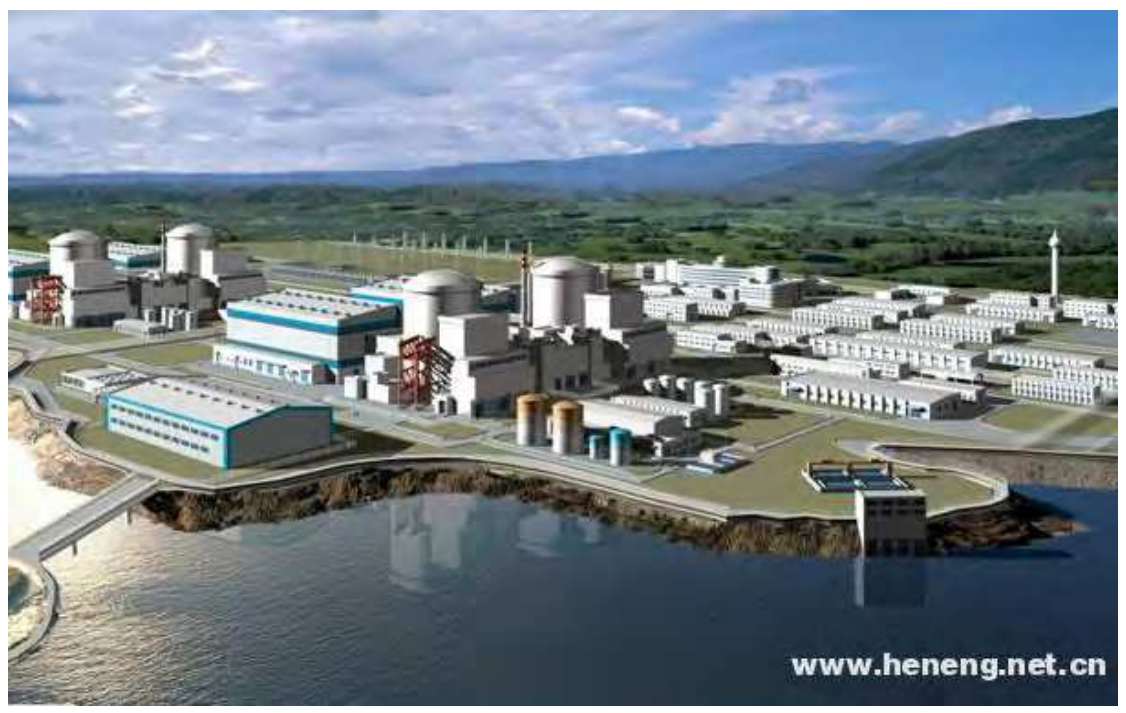

(2) Qinshan phase II (From http://www.heneng.net.cn/)

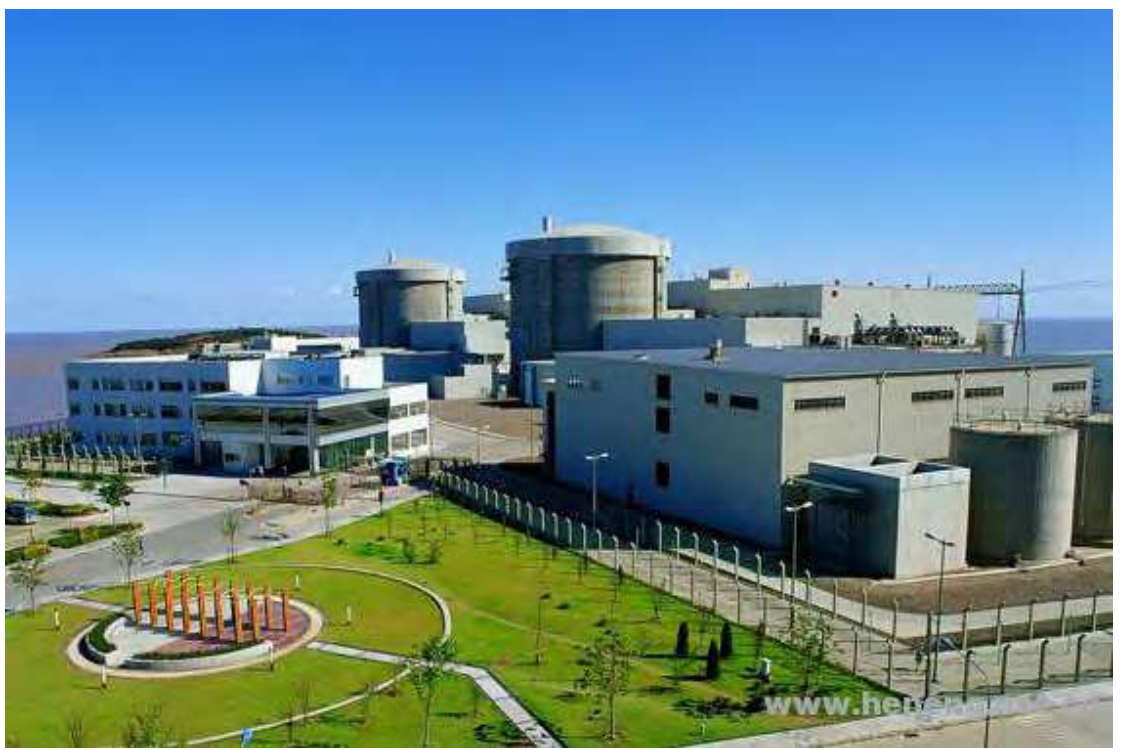

(3) Qinshan phase III (from http:/ / www.heneng.net.cn/)

C: Qinshan Nuclear Power Plant from the first to the third investment in China 


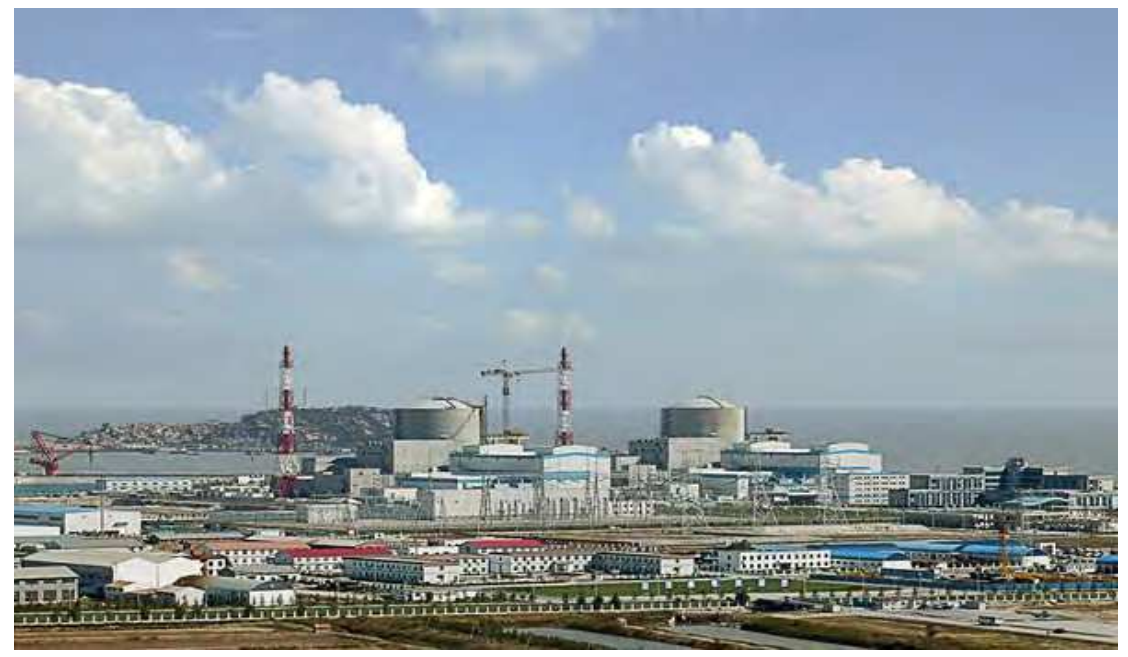

D: Tianwan Nuclear Power Plant in China (From http://www.heneng.net.cn/)

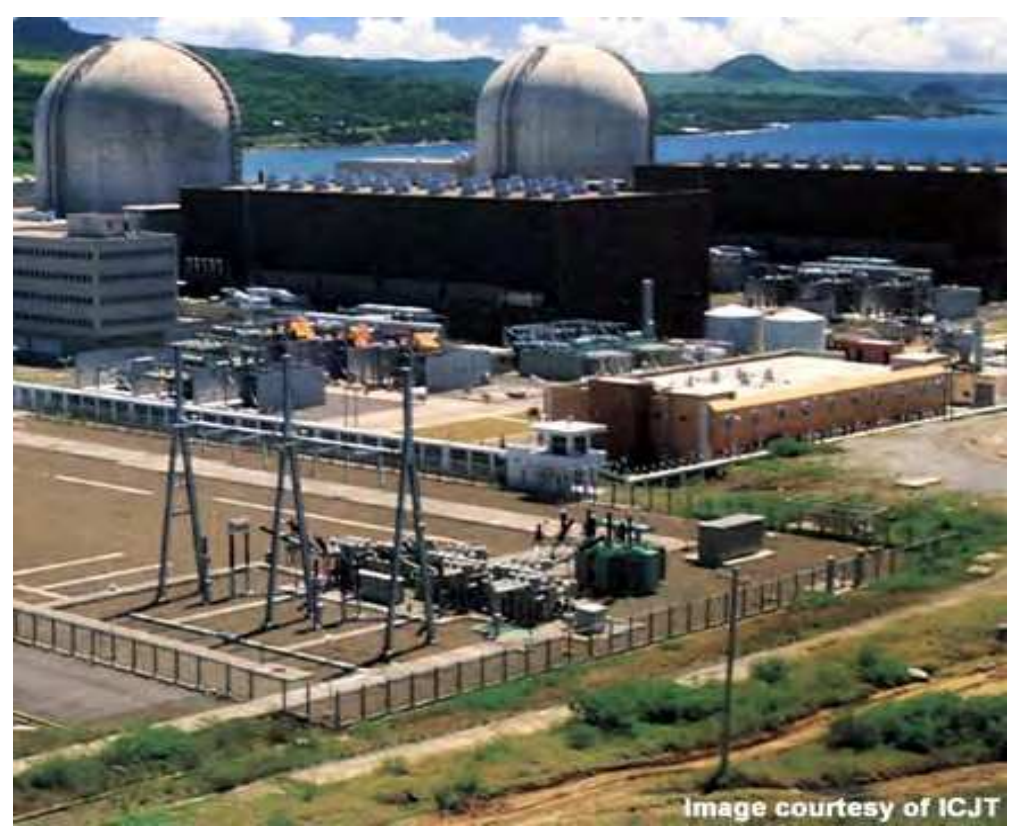

(1) Chinshan nuclear power plant (From http://www.power-technology.com/) 


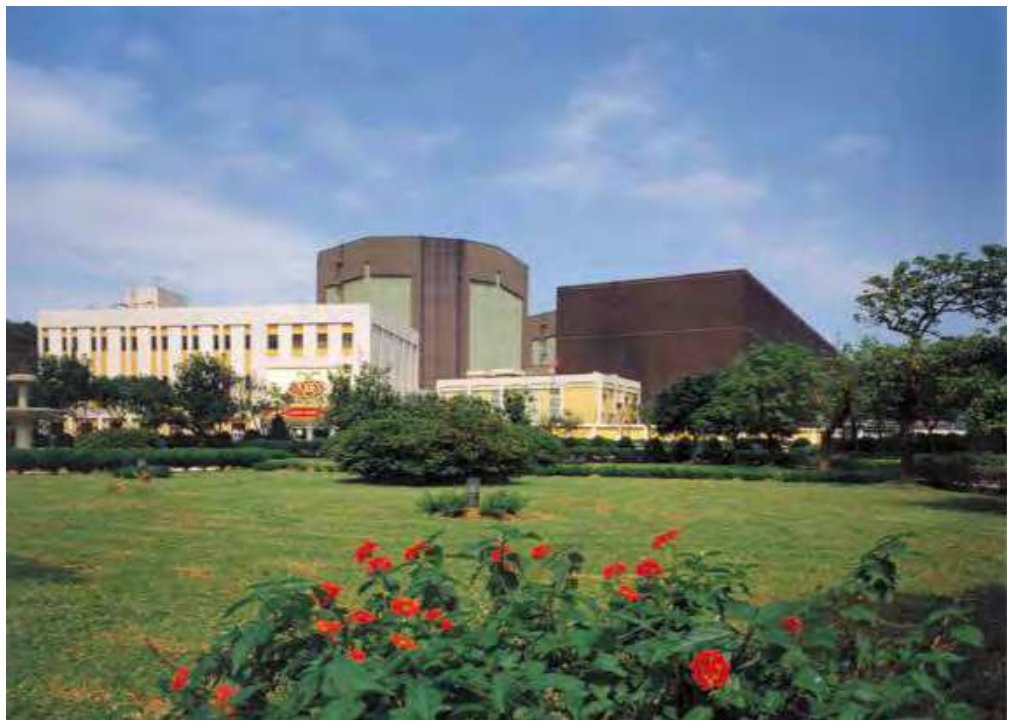

(2) Kuosheng nuclear power plant (From http://www.aesieap0910.org/)

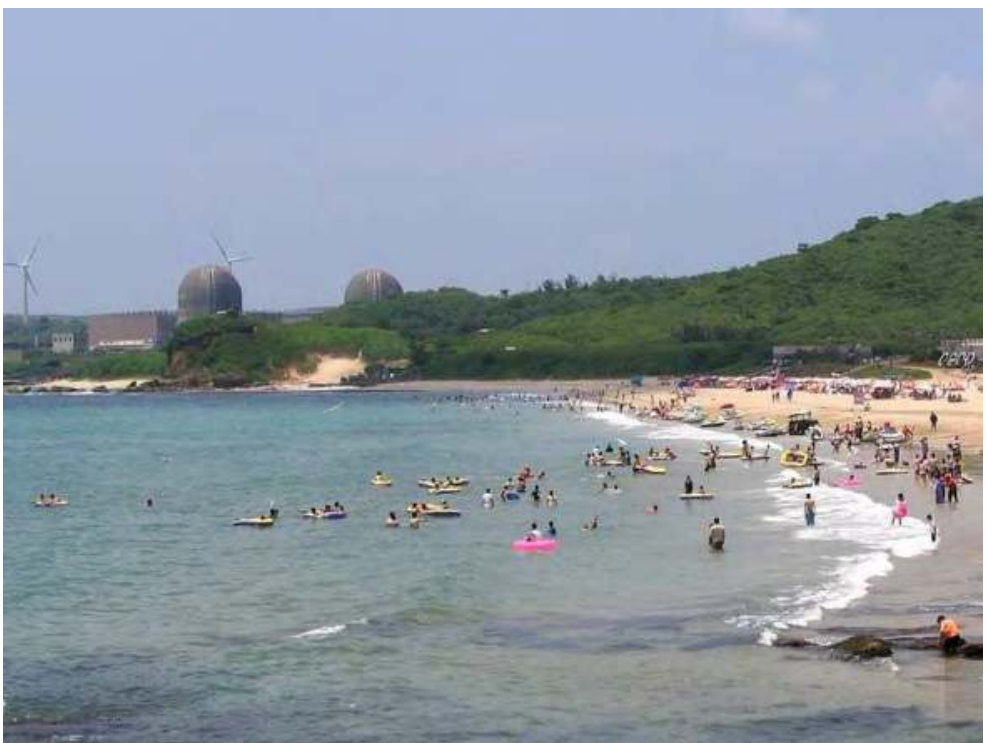

(3) Maanshan nuclear power plant (From http://commons.wikimedia.org/) 


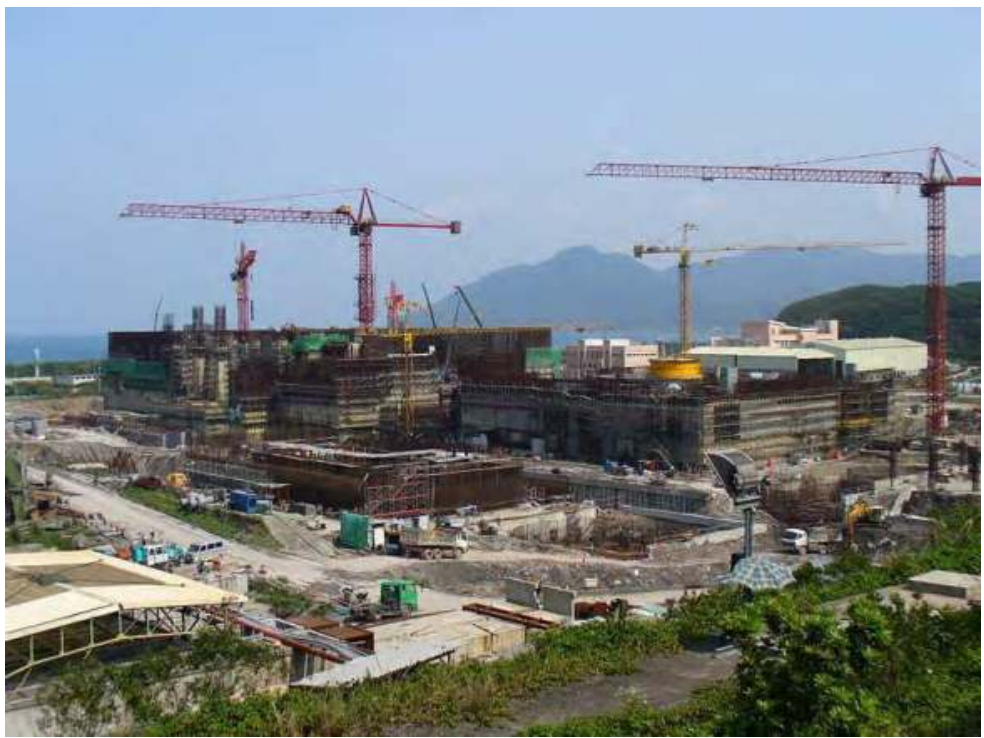

(4) Lungmen nuclear power plant (From http://commons.wikimedia.org/)

E: Nuclear Power Plants in Taiwan of China

\section{中国核电厂分布图}

Distribution of the NPPs

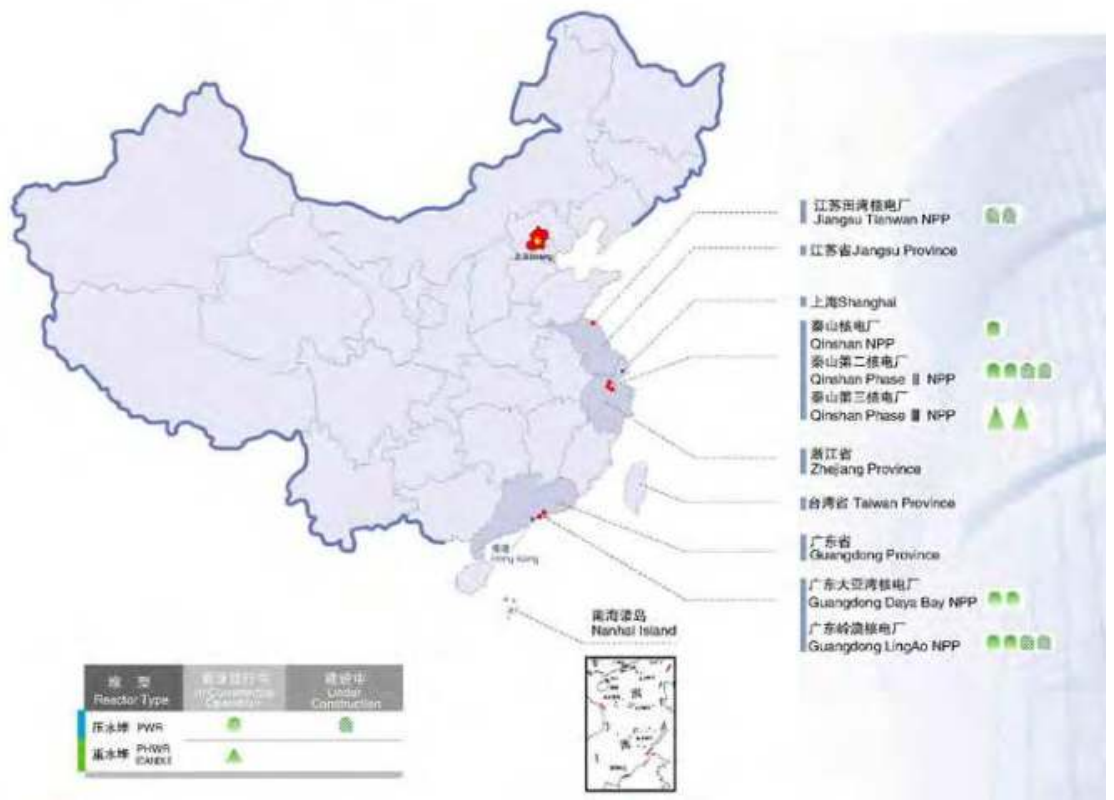

F: Distribution of the Nuclear Power Plants in China 


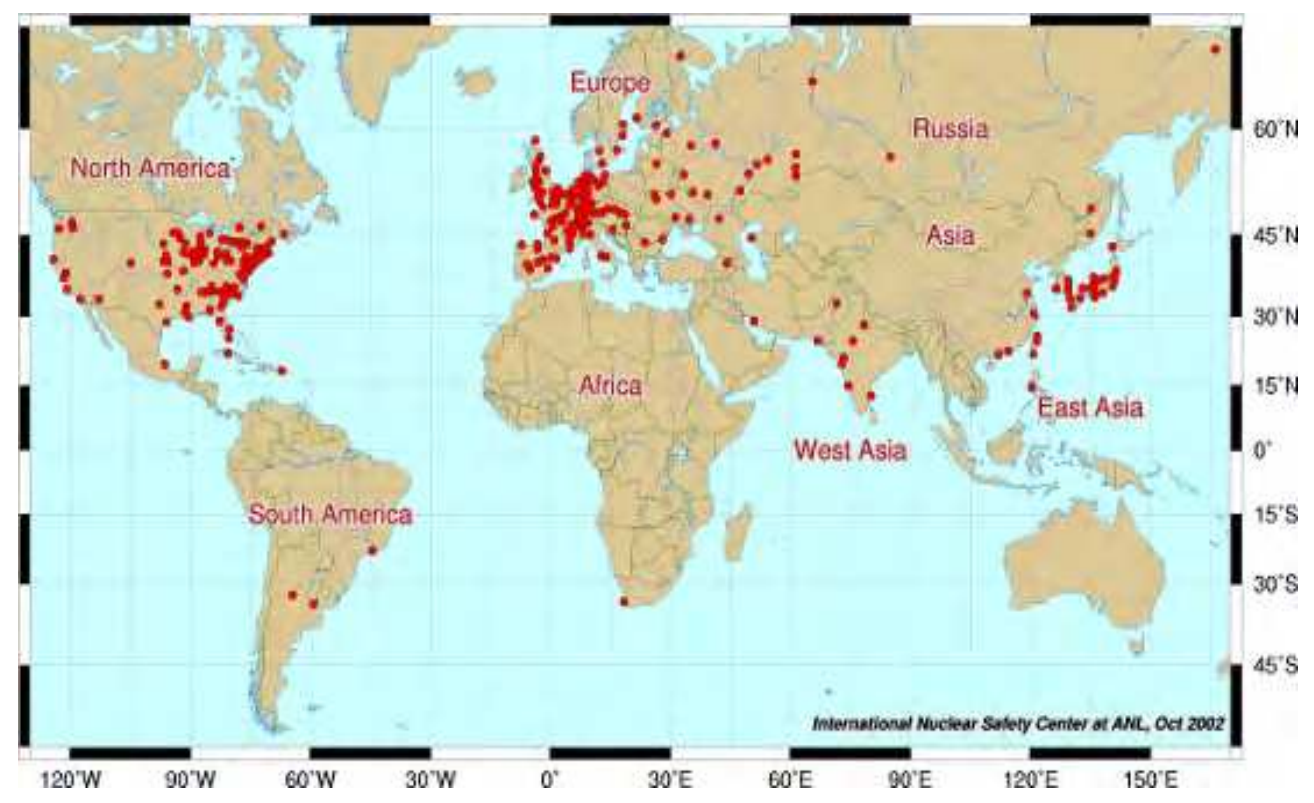

G: Distribution of the Nuclear Power Plants in the world

(From http://www.taizhou.com.cn/)

Fig. 4. Different Nuclear Power Plants for opening in China.

Another Nuclear Power Plant-Lingao Nuclear Power Plant (LNPP) near the Daya Bay Nuclear Power Plant has also run since 2002. These changes can also impacting on the ecological environment of Daya Bay (Zheng et al., 2001; Bodergat et al., 2003; Wu \& Wang, 2007; Wang et al., 2006, 2008, 2011) (Fig.5).

The variety of ecological and environmental factors in Daya Bay has been carried out since 1982, including 12 stations with four voyages per year. All stations were occupied between $113^{\circ} 29^{\prime} 42^{\prime \prime}-114^{\circ} 49^{\prime} 42^{\prime \prime} \mathrm{E}$ and $23^{\circ} 31^{\prime} 12^{\prime \prime}-24^{\circ} 50^{\prime} 00^{\prime \prime} \mathrm{N}$. The main marine monitoring investigation included the ecological environment, the ecological function of marine biological resources and the community organization etc in Daya Bay. Temperature and salinity of water were measured in the field using CTD probes. Sea-water samples for analysis of nutrients, dissolved oxygen, $\mathrm{pH}$, chemical oxygen demand, chlorophyll $a$ was taken using 5-L GO FLO bottles at surface and bottom layers, and other samples were collected according to the methods and sampling tools of "The specialties for oceanography survey" (GB12763-91, China). All sample analysis was carried out at National Field Station of Marine Ecosystem Research and Observation at Daya Bay, Shenzhen, China and at South China Sea Institute of Oceanology, Chinese Academy of Sciences. Analytical methods for the various physicalchemical and biological parameters are applied according to Wang et al (2006, 2008, 2011).

All these samples were collected during one day at the beginning of the first month of each season (spring-summer-fall-winter). The samples (except phytoplankton, zooplankton, benthos and fish) included those taken at the surface and the bottom, and the data for this paper are given as mean values between the surface and bottom. 


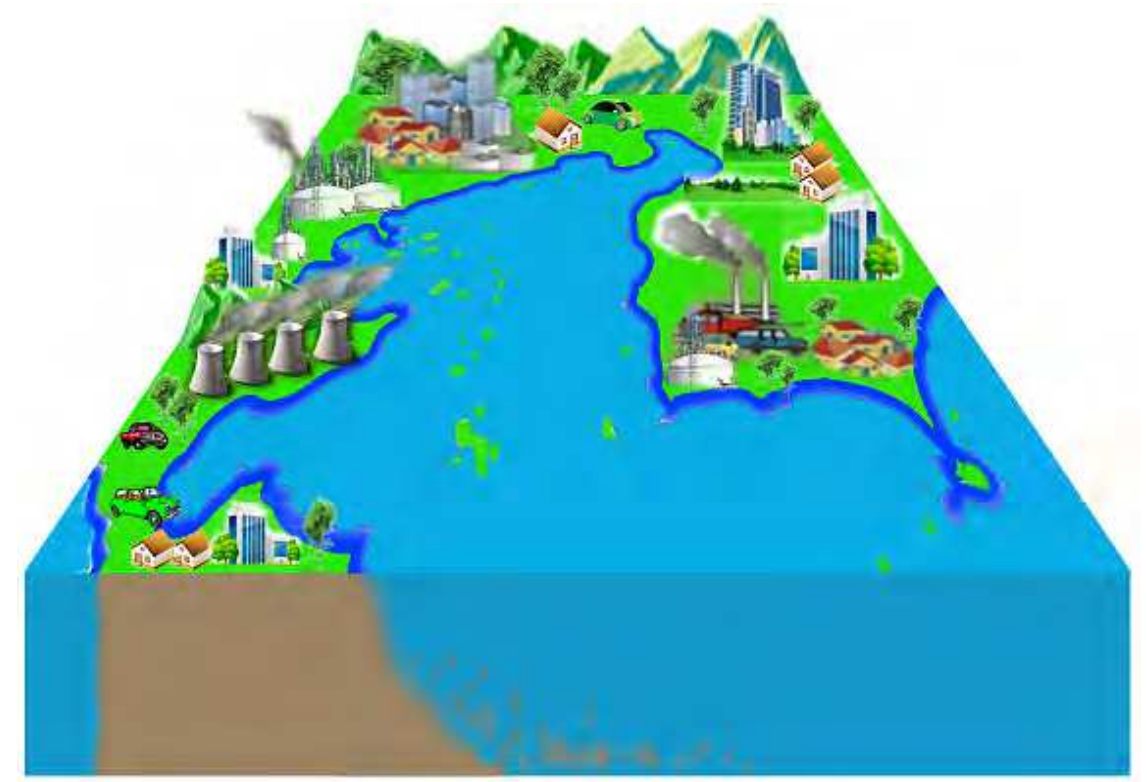

Fig. 5. Daya Bay and it's around environments.

\section{Statistical analysis}

All statistical analysis methods were used according to Johnson \& Wichern (1998). Kendall's tau-b values were used to measure the degree of association among various variables with bivariate statistical analysis. Bivariate correlations between the biomass of phytoplankton and benthos and major physical and nutrient factors were calculated for all stations. Flexible-Beta cluster analysis was used between groups transforming the measures with Flexible-Beta Distance. Factor analysis techniques were used to investigate the various factors that are present in each of the three clusters identified by cluster analysis (using PROC X16 of the SAS system) (Wang et al., 2006, 2011). All statistical analysis programs are part of the Statistical Analysis System (SAS 9.0) software package (SAS Institute Incorporation).

\section{Results and discussion}

\subsection{Long-term changes of Daya Bay}

Spatial distribution of water temperature showed high values in the western near the nuclear power stations and low values in the mouth of Daya Bay all the years. Stratification due to temperature and salinity differences between surface and bottom waters inside the bay start to develop in June, become strongest from July to September, and disappear in November; temperature and salinity were uniformly distributed with depth from November to May in the following year (Xu, 1989; Wang et al., 2006, 2008, 2011). Changes of temperature and salinity in Daya Bay varying by seasons are shown in Fig. 6 and 7. Annual mean value of temperature was $24.04^{\circ} \mathrm{C}$ based on the data measured from 1982 to 2004 , the highest surface and bottom water temperatures occurred in August and the lowest values were in January (Wang et al., 2006, 2008, 2011). 
Effects of the Operating Nuclear Power Plant

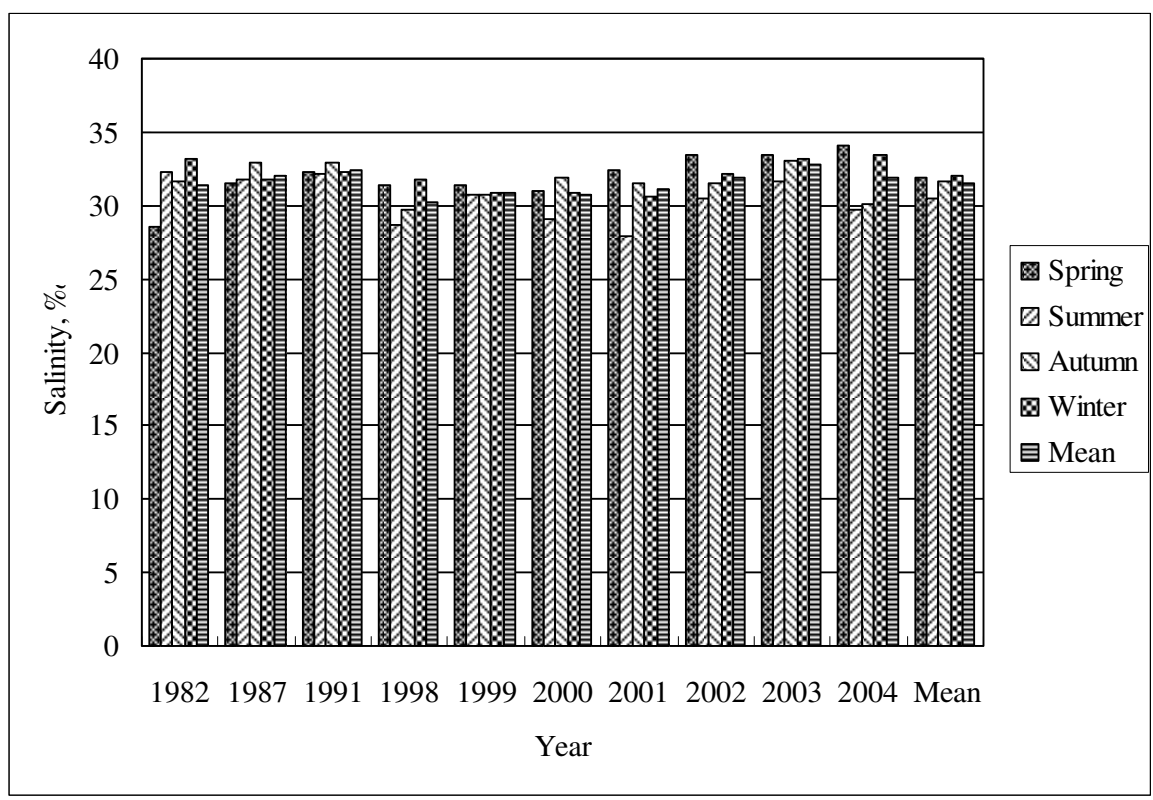

Fig. 6. Salinity of Daya Bay with different seasons from 1982 to 2004 (Wang et al., 2008) (Unit:\%o).

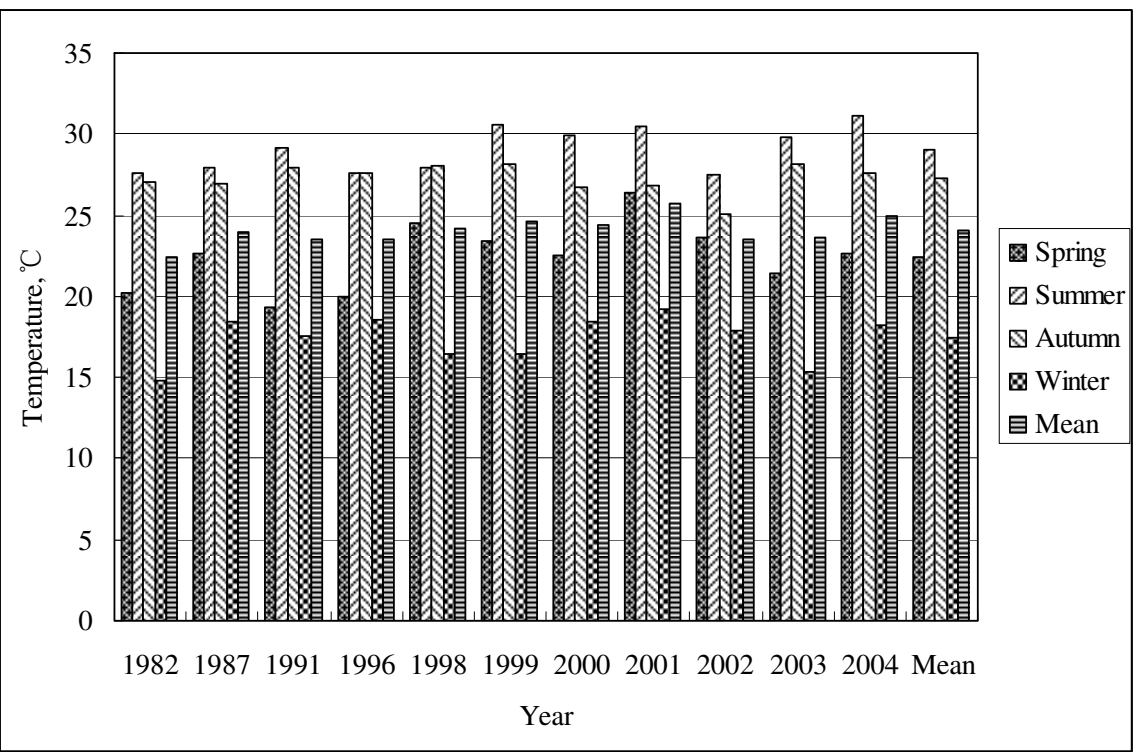

Fig. 7. Temperature of Daya Bay with different seasons from 1982 to 2004 (Wang et al., 2008) (Unit: $\left.{ }^{\circ} \mathrm{C}\right)$. 
Cold-water upwelling influenced the distribution of nutrients and temperature, fluctuates in Daya Bay. The vertical and seasonal variations and distribution of water temperature suggest that the bay is affected by the East Guangdong upwelling and a thermocline occurring during June-August (Han, 1991; Wang et al., 2006, 2008, 2011). During this time, the thermocline temperature gradient averaged $0.5-1^{\circ} \mathrm{C} \mathrm{m}^{-1}$. The depths of the thermocline are $\sim 6-10 \mathrm{~m}$ with a thickness of $\sim 2-4 \mathrm{~m}$ in Daya Bay (Wang et al., 2006, 2008, 2011). The thermocline disappeared from November to the following May due to the mixing of the seawater.

The seasonal variation of temperature of Daya Bay from 1982 to 2004 is shown in Fig.7. Annual mean temperatures were increasing from 1982 to 2004, probably due to Global Change. Climate change scenarios for the year 2100 indicates a significant increase in air temperature (by $2.3-4.5^{\circ} \mathrm{C}$ ) which is major factor influencing the environment of the Gulf (Kont et al., 2003). The temperature of western Daya Bay near the Nuclear Power Plants was higher than those in the other sea area in Daya Bay, by about $1^{\circ} \mathrm{C}$, mainly due to waste warm water discharged to the south area of Daya Bay from the Nuclear Power Plants (Fig.8) which directly impact on the ecological environment of Daya Bay (Wang et al., 2006, 2008, 2011; Zheng et al., 2001). Assuming the temperature of the waste water from the nuclear power plant to be $1^{\circ} \mathrm{C}$ warmer than the surrounding seawater, then the area of Daya Bay affected by this warmer water was about $5.51 \mathrm{~km}^{2}$ (Han, 1991; Wang et al., 2006).

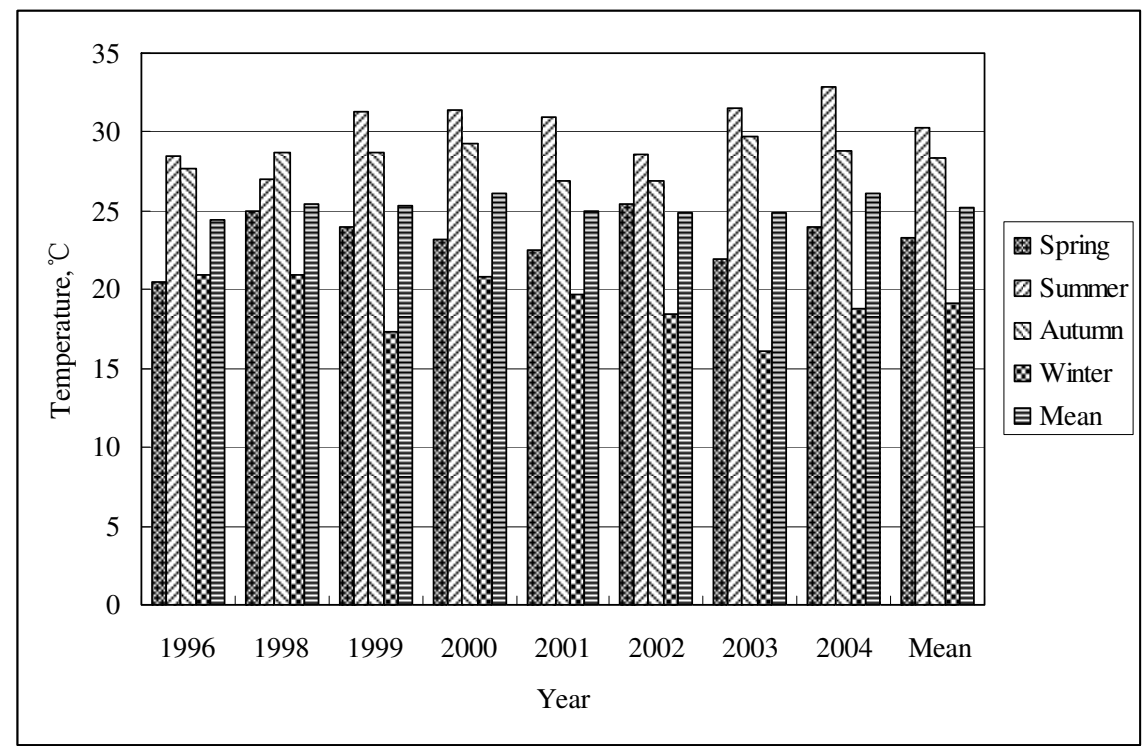

Fig. 8. Temperature of western Daya Bay with different seasons from 1996 to 2004 (Wang et al., 2008) (Unit: $\left.{ }^{\circ} \mathrm{C}\right)$.

Spatial distribution of dissolved oxygen (DO) in Daya Bay was as uniform as temperature, seasonal variations were evident from 1982 to 2004 (Fig.9). Distributions of dissolved oxygen in spring and winter were higher than in summer and autumn. The highest dissolved oxygen content occurred in winter and the lowest in summer. There was a decreased from $7.29 \mathrm{mg} \mathrm{l}^{-1}$ to $7.03 \mathrm{mg} \mathrm{l}^{-1}$ of the dissolved oxygen from 1991 to 2002, probably due to the progressive increases in sea surface temperature increasing of Daya Bay (Fig.7). Although the results 
indicate there was a small decreasing trend in the dissolved oxygen (DO), the seawater of Daya Bay was also within the First Class of National Seawater Quality Standards for China (>6.00 $\mathrm{mg} \mathrm{l}^{-1}$, GB3097-1997) (Wang et al., 2003, Wang et al., 2006, 2008, 2011). Annual mean pH variation was at 8.15 to 8.25 from 1982 to 2004, with a little change in Daya Bay (Fig.10). The results also indicated that ocean acidification is very clear in Daya Bay (Kerr, 2010).

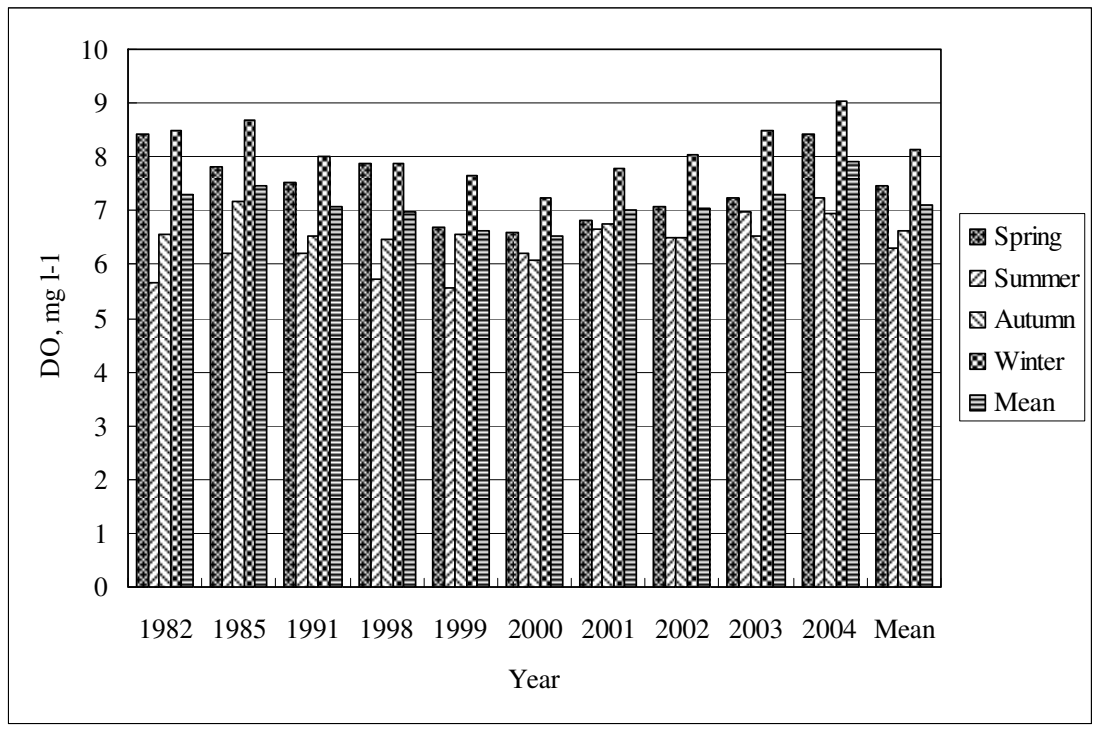

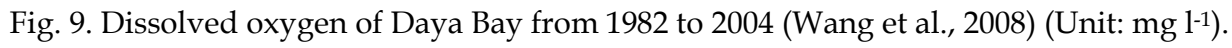

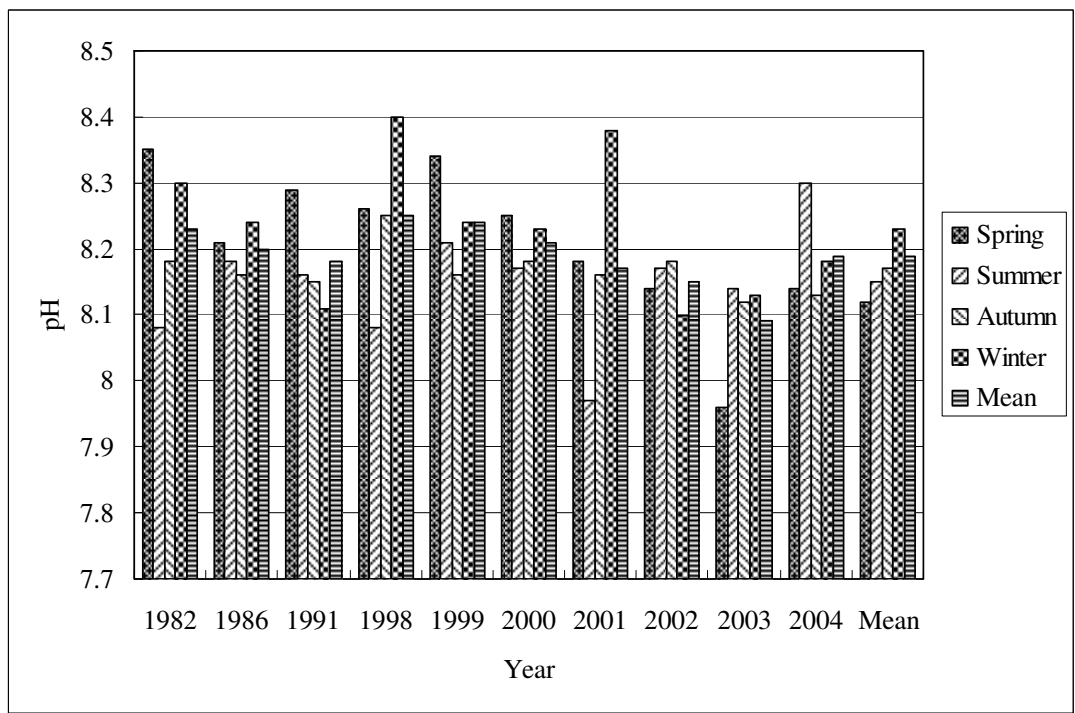

Fig. 10. pH of Daya Bay with different seasons from 1982 to 2004 (Wang et al., 2008). 
The chemical oxygen demand (COD) values were $0.63-1.18 \mathrm{mg} \mathrm{l}^{-1}$ in Daya Bay from 1989 to 2004 (Fig.11, Wang et al., 2008). The mean chemical oxygen demand values were lower than the other sea areas in China, such as the COD is between $2.90 \mathrm{mg} \mathrm{dm}^{-3}$ and $7.50 \mathrm{mg} \mathrm{dm}^{-3}$ in the Pearl River Estuary (Lin \& Li, 2003) and from $3.32 \mathrm{mg} \mathrm{l}^{-1}$ to $4.01 \mathrm{mg} \mathrm{l}^{-1}$ in Rongcheng Bay in temperate zone (Mu et al., 1999). The chemical oxygen demand values also indicated that the organic pollution in Daya Bay was much lower than the other sea areas in China. The results of chemical oxygen demand in Daya Bay show that the sea water was also within the First Class of National Seawater Quality Standards for China ( $\leq 2.00 \mathrm{mg} \mathrm{l}^{-1}$, GB3097-1997) (Wang et al., 2003; Wang et al., 2006, 2008, 2011).

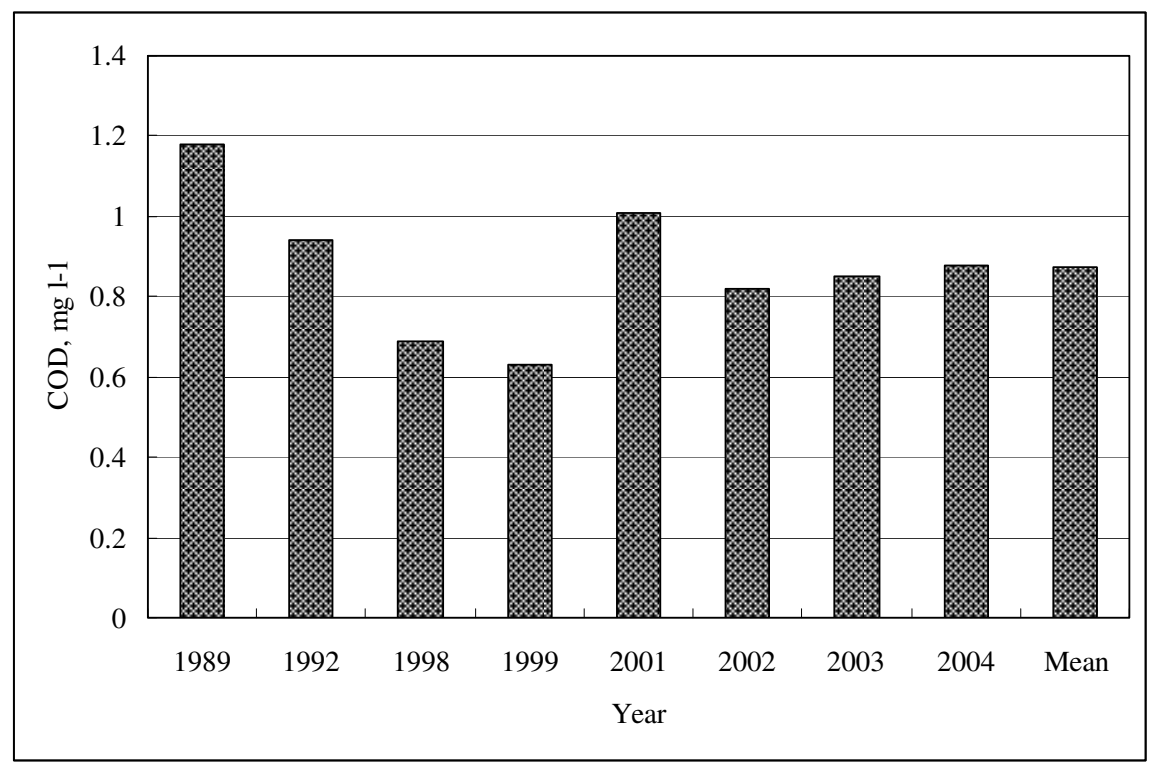

Fig. 11. Chemical oxygen demand of Daya Bay from 1989 to 2004 (Wang et al., 2008) (Unit: $\mathrm{mg} \mathrm{l}^{-1}$ ).

Inorganic $\mathrm{N}$ and P levels were low from $1.53 \mu \mathrm{mol} \mathrm{l}^{-1}$ to $5.40 \mu \mathrm{mol} \mathrm{l}^{-1}$ and from $0.0945 \mu \mathrm{mol} \mathrm{\textrm {l } ^ { - 1 }}$ to $1.12 \mu \mathrm{mol} \mathrm{l}^{-1}$, and mean values were $3.68 \mu \mathrm{mol} \mathrm{l}^{-1}$ and $0.266 \mu \mathrm{mol} \mathrm{l^{-1 }}$ from 1985 to 2004 within the National First Class Water Quality Standards for China (Wang et al., 2003; Wang et al., 2008) (Table1). These results are similar to the inorganic $\mathrm{N}$ and $\mathrm{P}$ levels of Mirss Bay in Hong Kong (Yin et al., 2003). $\mathrm{NH}_{4}-\mathrm{N}$ (about 49\%) and $\mathrm{NO}_{3}-\mathrm{N}$ (about 43\%) were the dominant total inorganic nitrogen (TIN) form, which account for about $90 \%$ of the TIN and $8 \%$ of $\mathrm{NO}_{2}-\mathrm{N}$ in recent years. The $\mathrm{NO}_{3}-\mathrm{N}$ content was lower than the $\mathrm{NH}_{4}-\mathrm{N}$, revealing a thermodynamic imbalance between $\mathrm{NH}_{4}-\mathrm{N}, \mathrm{NO}_{2}-\mathrm{N}$ and $\mathrm{NO}_{3}-\mathrm{N}$. Biological activity might be also the main factor influencing the balance (Huang et al., 2003; Wang et al., 2008), but there were different degrees of transformation of $\mathrm{NH}_{4}-\mathrm{N}$ for the different bay regions. The concentration of both $\mathrm{N}$ and $\mathrm{Si}$ were higher than inorganic P. Spatially the nutrients $\mathrm{N}$ increases from 1985 to 2004 in Daya Bay, probably as results of the waste water of the people lived along the coast, the land sources (such as Nanchong River, Longqi River and Pengcheng River discharge into Dapeng Cove and unclear power plants waste water 
discharge into the south area of Daya Bay), seawater breed aquatics and the effect of the water from the Preal River on Daya Bay (Han, 1991). The nutrient P decreased from 1.12

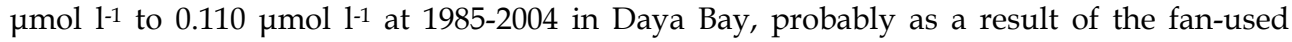
detergency powder contain-P in recent years. The average ratio of TIN/P increased from 1.377 in 1985 to 49.09 in 2004, and the highest value was 61.90 in 2003. The average ratio of Si/P increased from 35.27 to 285.82 at 1985-2004 (Wang et al., 2008). The limiting nutrients in Daya Bay has changed from N to P from 1985 to 2004 (Justice et al., 1995), and is different from those at Jiaozhou Bay which shifted from N and/or P to Si from the 1960s to the 1990s in temperate zone (Shen, 2001) and Sanya Bay which shifted from $\mathrm{N}$ in summer and autumn to $\mathrm{P}$ in winter in Sanya Bay from 1998 to 2000 in tropic zone (Huang et al., 2003).

\begin{tabular}{ccccccccc}
\hline Year & $\mathrm{NH}_{4}^{+}$ & $\mathrm{NO}_{2}^{-}$ & $\mathrm{NO}_{3}^{-}$ & $\mathrm{TIN}$ & $\mathrm{SiO}_{3}^{2-}$ & $\mathrm{PO}_{4}^{3-}$ & $\mathrm{TIN} / \mathrm{P}$ & $\mathrm{Si} / \mathrm{P}$ \\
\hline 1985 & 0.698 & 0.230 & 0.602 & 1.53 & 39.50 & 1.12 & 1.377 & 35.27 \\
1989 & 0.607 & 1.10 & 1.52 & 3.23 & 10.85 & 0.377 & 8.560 & 28.78 \\
1991 & 1.10 & 0.230 & 0.798 & 2.13 & 20.66 & 0.358 & 5.950 & 57.71 \\
1997 & 1.38 & 0.150 & 2.55 & 4.08 & 14.57 & 0.122 & 33.44 & 119.43 \\
1998 & 1.86 & 0.0554 & 0.433 & 2.35 & 5.125 & 0.0405 & 57.99 & 126.54 \\
1999 & 1.99 & 0.389 & 2.46 & 4.84 & 9.810 & 0.118 & 40.02 & 76.46 \\
2000 & 1.59 & 0.508 & 1.92 & 4.01 & 27.54 & 0.252 & 15.91 & 109.29 \\
2001 & 2.28 & 0.134 & 1.93 & 4.33 & 23.21 & 0.229 & 18.91 & 101.35 \\
2002 & 1.32 & 0.446 & 0.680 & 2.40 & 27.01 & 0.0945 & 25.40 & 285.82 \\
2003 & 2.54 & 0.260 & 3.39 & 6.19 & 23.06 & 0.100 & 61.90 & 230.60 \\
2004 & 3.06 & 0.085 & 2.25 & 5.40 & 12.82 & 0.110 & 49.09 & 116.54 \\
\hline Mean & 1.68 & 0.326 & 1.68 & 3.68 & 19.47 & 0.266 & 28.96 & 117.07 \\
\hline
\end{tabular}

${ }^{*}$ Quality Standards of Seawater from GB3097-1997, TIN: China first class $\left(\mu \mathrm{mol} \mathrm{1} \mathrm{l}^{-1}\right) \leq 14.28$, second class $\left(\mu \mathrm{mol} \mathrm{l}{ }^{-1}\right) \leq 21.43 ; \mathrm{PO}_{4}-\mathrm{P}$ : China first class $\left(\mu \mathrm{mol} \mathrm{l}^{-1}\right) \leq 0.4839$, second class $\left(\mu \mathrm{mol} \mathrm{l}^{-1}\right) \leq 0.9677$.

Table 1. Concentrations of different forms N, $\mathrm{SiO}_{3}-\mathrm{Si}$ and $\mathrm{PO}_{4}-\mathrm{P}$ in Daya Bay at 1985-2004 (Wang et al., 2008) (Unit: $\mu \mathrm{mol} \mathrm{l}^{-1}$ ).

\begin{tabular}{ccccccccccc}
\hline Phylum & 1982 & 1983 & 1985 & 1987 & 1990 & 1994 & 1998 & 2002 & 2003 & 2004 \\
\hline $\begin{array}{c}\text { Bacillario- } \\
\text { phyta }\end{array}$ & $37 / 134$ & $38 / 120$ & $38 / 127$ & $41 / 137$ & $37 / 140$ & $25 / 78$ & $24 / 72$ & $25 / 96$ & $31 / 92$ & $34 / 100$ \\
$\begin{array}{c}\text { Pyrophyta } \\
\text { Cyanophyta }\end{array}$ & $9 / 25$ & $9 / 32$ & $8 / 30$ & $8 / 27$ & $17 / 61$ & $10 / 30$ & $5 / 8$ & $9 / 27$ & $12 / 30$ & $8 / 23$ \\
$\begin{array}{c}\text { Total (Genera } \\
\text { / Species) }\end{array}$ & $46 / 159$ & $48 / 155$ & $49 / 160$ & $51 / 4$ & $2 / 5$ & $1 / 2$ & 0 & $2 / 4$ & $2 / 3$ & $2 / 3$ \\
\hline
\end{tabular}

Table 2. Species, genera of the phytoplankton of Daya Bay from 1982 to 2004 (Wang et al., 2008).

About 300 species of phytoplankton have been identified in Daya Bay since 1982 (Xu, 1989; Wang et al., 2008). They belong to Cyanophyta, Bacillariophyta, Pyrophyta, Chrysophyta and Xanthophyta etc. Most of them are diatoms (about 70\%) and chaetocero (about 20\%). Of the 183 species of diatoms, chaetoceros had many more species than other genera (45 spp), followed by Rhizosolenia (23 spp) and Coscinodiscus (22 spp) (Yang, 1990; Wang et al., 2008). 
The main dominant species of Daya Bay are Chaetoceros, Nitzschia, Rhizosolenia, Leptocylindrus and Skeletonema, such as Chaetoceros affinis, Chaetoceros compressus, Chaetoceros lorenzianus, Ch. Curvisetus, Ch. Pseudocurvisetus, Rhiz. alata f.grecillisma, Nitzschia delicatissima, Leptocylindrus danicua, Skeletonema costatum and Thalassionema nitzschioide, the chaetocero is Ceratium sp. as the dominant species. The phytoplankton species have been gradually decreasing since 1990s as compared to those during 1980s (Table 2). In particularly, there was only 80 species in 1998. The phytoplankton cell density has been also gradually decreasing since 1998 compared with 1985. Annual mean values of the phytoplankton in Daya Bay were between $8.88 \times 10^{5}$ and $6.63 \times 10^{7}$ cells $\mathrm{m}^{-3}$ at $1985-2004$. Phytoplankton abundance peaked in spring at $1.03 \times 10^{8}$ cells $\mathrm{m}^{-3}$ in 1985 (Table 3) and was lowest in spring at $7.30 \times 10^{4}$ cells $\mathrm{m}^{-3}(1 / 1411)$ in 1999. Although the mean annual abundances of phytoplankton show a slight decrease trend from 1999 to 2004, species and values of the phytoplankton of Daya Bay were increasing that might be due to high ratios of TIN to P and Si to P occurring in recent years (Sommer et al., 2002). Annual mean values of chlorophyll $a$ were $1.83-3.78 \mathrm{mg} \mathrm{m}^{-3}$ in different seasons from 1985 to 2004 , the higher values were always found in autumn and summer. The nutrient structure has become more balanced for phytoplankton growth (Shen, 2001).

\begin{tabular}{|c|c|c|c|c|c|c|c|c|c|}
\hline Season & Production & 1985 & 1998 & 1999 & 2000 & 2001 & 2002 & 2003 & 2004 \\
\hline & Chl $a\left(\mathrm{mg} \mathrm{m}^{-3}\right)$ & 2.06 & 1.46 & 2.00 & 0.979 & 1.49 & 0.830 & 5.88 & 1.94 \\
\hline \multirow[t]{2}{*}{ Spring } & $\begin{array}{l}\text { Phytoplankton } \\
\left(\text { cells } \mathrm{m}^{-3}\right)\end{array}$ & $1.03 \times 10^{8}$ & $2.16 \times 10^{7}$ & $7.30 \times 10^{4}$ & $5.27 \times 10^{6}$ & $6.59 \times 10^{5}$ & $1.71 \times 10^{6}$ & $1.53 \times 10^{5}$ & $3.43 \times 10^{6}$ \\
\hline & Zooplankton (ind $\mathrm{m}^{-3}$ ) & 109.20 & 28.90 & - & 90.00 & 34.97 & 135.29 & 137.58 & 204.67 \\
\hline \multirow{3}{*}{ Summer } & $\mathrm{Chl} a\left(\mathrm{mg} \mathrm{m}^{-3}\right)$ & 2.36 & 1.44 & 3.44 & 4.07 & 1.32 & 6.09 & 1.91 & 3.93 \\
\hline & $\begin{array}{l}\text { Phytoplankton } \\
\left(\text { cells } \mathrm{m}^{-3}\right)\end{array}$ & $9.61 \times 10^{7}$ & $7.59 \times 10^{5}$ & $6.28 \times 10^{5}$ & $5.25 \times 10^{7}$ & $9.31 \times 10^{5}$ & $1.87 \times 10^{6}$ & $2.45 \times 10^{6}$ & $1.66 \times 10^{7}$ \\
\hline & Zooplankton (ind $\mathrm{m}^{-3}$ ) & 578.90 & 82.70 & - & - & 404.08 & 248.62 & 191.97 & 131.33 \\
\hline \multirow{3}{*}{ Autumn } & $\mathrm{Chl} a\left(\mathrm{mg} \mathrm{m}^{-3}\right)$ & 1.19 & 3.50 & 4.69 & 3.46 & 2.25 & 2.82 & 1.44 & 1.67 \\
\hline & $\begin{array}{l}\text { Phytoplankton } \\
\left(\text { cells } \mathrm{m}^{-3} \text { ) }\right.\end{array}$ & $1.53 \times 10^{7}$ & $6.00 \times 10^{6}$ & $1.02 \times 10^{6}$ & $3.86 \times 10^{5}$ & $5.63 \times 10^{5}$ & $3.70 \times 10^{5}$ & $1.99 \times 10^{5}$ & $3.49 \times 10^{5}$ \\
\hline & Zooplankton (ind $\mathrm{m}^{-3}$ ) & 523.90 & 43.65 & - & - & 131.11 & 258.80 & 58.41 & 581.15 \\
\hline \multirow{3}{*}{ Winter } & $\mathrm{Chl} a\left(\mathrm{mg} \mathrm{m}^{-3}\right)$ & 1.70 & 1.77 & 5.01 & 1.85 & 2.81 & 2.98 & 3.32 & 2.06 \\
\hline & $\begin{array}{l}\text { Phytoplankton } \\
\left(\text { cells } \mathrm{m}^{-3}\right)\end{array}$ & $3.77 \times 10^{7}$ & $6.73 \times 10^{6}$ & $1.83 \times 10^{6}$ & $8.49 \times 10^{4}$ & $2.74 \times 10^{6}$ & $6.21 \times 10^{5}$ & $2.24 \times 10^{6}$ & $3.63 \times 10^{6}$ \\
\hline & Zooplankton (ind $\mathrm{m}^{-3}$ ) & 189.30 & 66.41 & 94.72 & - & 204.16 & 455.54 & 309.32 & 619.05 \\
\hline \multirow{3}{*}{ Mean } & $\mathrm{Chl} a\left(\mathrm{mg} \mathrm{m}^{-3}\right)$ & 1.83 & 2.04 & 3.78 & 2.63 & 1.97 & 3.18 & 3.14 & 2.40 \\
\hline & $\begin{array}{l}\text { Phytoplankton } \\
\left(\text { cells } \mathrm{m}^{-3}\right)\end{array}$ & $6.30 \times 10^{7}$ & $8.77 \times 10^{6}$ & $8.88 \times 10^{5}$ & $1.46 \times 10^{7}$ & $1.22 \times 10^{6}$ & $1.14 \times 10^{6}$ & $1.60 \times 10^{6}$ & $6.00 \times 10^{6}$ \\
\hline & Zooplankton (ind $\mathrm{m}^{-3}$ ) & 352.70 & 55.42 & 94.72 & 90.00 & 193.58 & 283.56 & 174.32 & 384.05 \\
\hline
\end{tabular}

Table 3. Seasonal production measurements in Daya Bay from 1985 to 2004 (Wang et al., 2008).

Seasonal changes of chlorophyll $a$ near the nuclear power plant are shown in Fig.12 (Wang et al., 2008). Annual mean values of chlorophyll $a$ near Nuclear Power Plant were 1.37-2.45 $\mathrm{mg} \mathrm{m}^{-3}$ before operation and $2.46-3.34 \mathrm{mg} \mathrm{m}^{-3}$ after operation the first Nuclear Power Plant at 1991-1997. Seasonal changes of primary productivity near the nuclear power plant are very different between before operation and after operation the first Nuclear Power Plant at 1991-1997 (Fig.13). The waste warm water can give an increase for chlorophyll $a$ and primary productivity near the nuclear power plants. The waster warm water can provide extra amount of energy for phytoplankton growth (Wang et al., 2006). 
265 species of zooplankton sampled from Daya Bay have been studied since 1982 (Wang et al., 2008). They can be divided into four ecological forms: estuary and inner bay type, warm coastal type and warm open sea type (Lian et al., 1990). The latter two types account for most of the species. Variations of dominant species exhibited a seasonal succession. The abundance of zooplankton varied seasonally, the maximum number of individuals occurred in autumn. Although main species of the zooplankton in Daya Bay had a decreasing trend from 46 of 60 familiar species in 1983 to 36 of 60 familiar species in 2004 (Fig.14), the annual mean individual

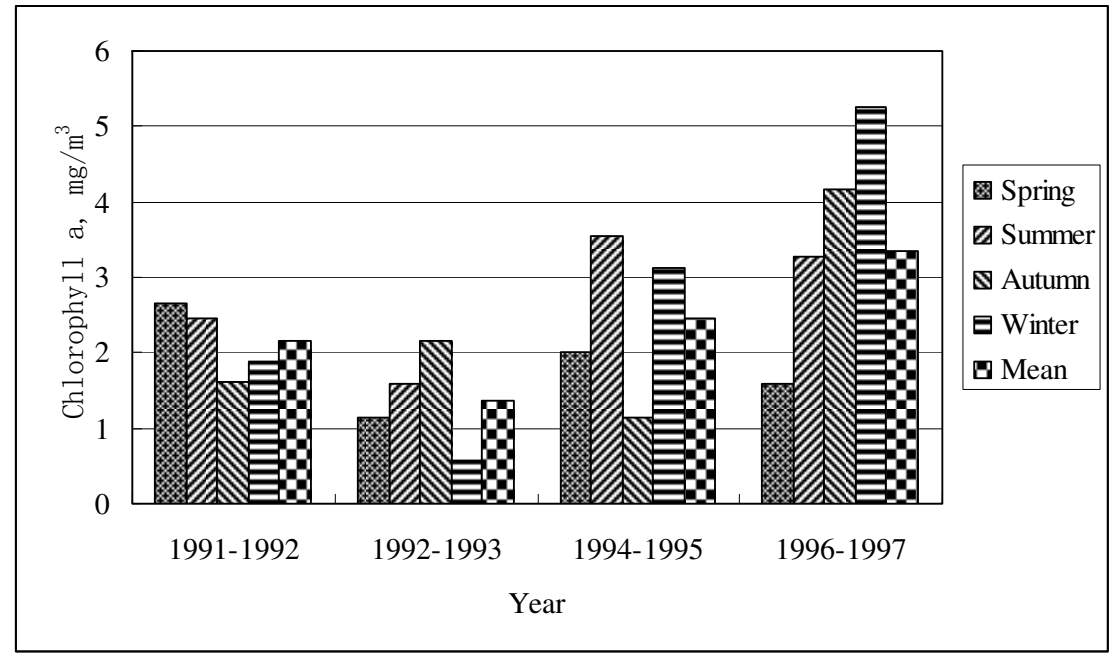

Fig. 12. Seasonal changes of chlorophyll $a$ near the Nuclear Power Plant $\left(\mathrm{mg} / \mathrm{m}^{3}\right)$.

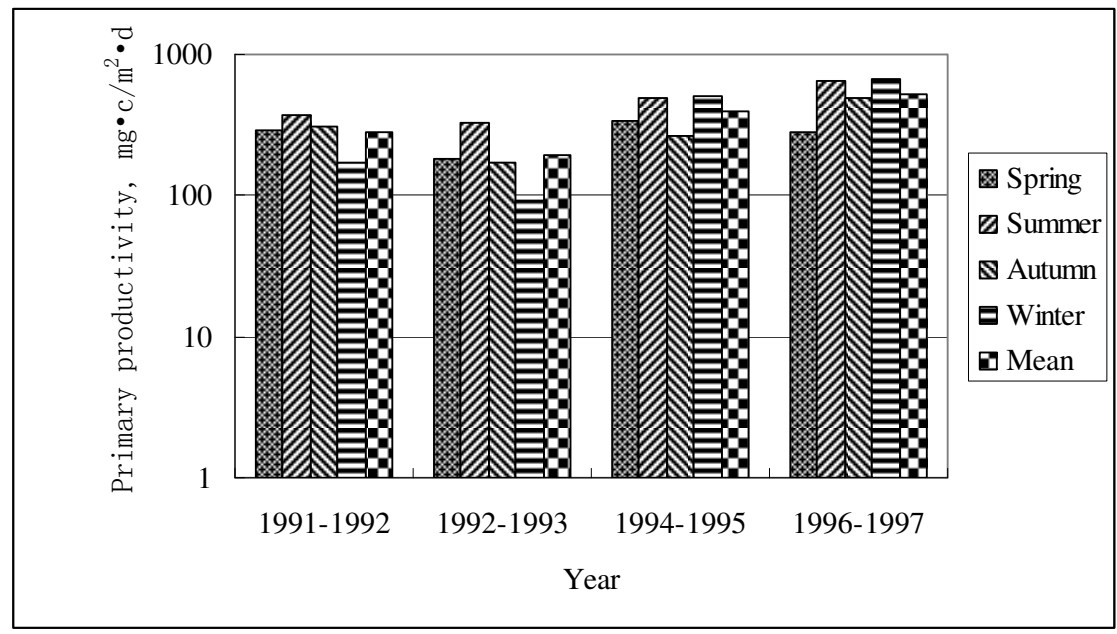

Fig. 13. Seasonal changes of primary productivity near the Nuclear Power Plant $\left(\mathrm{mg} \cdot \mathrm{c} / \mathrm{m}^{2} \cdot \mathrm{d}\right)$. 
number of zooplankton has been gradually increasing from 55.42 ind $\mathrm{m}^{-3}$ to 384.05 ind $\mathrm{m}^{-3}$ since 1998, and the value in 2004 has already exceed the 352.70 ind $\mathrm{m}^{-3}$ level in 1985 (Table $3)$. One reason might be the strictly enforced regulations relating to the marine environment and fisheries from June to August in each year since 1995, and another reason might be high levels of plant nutrients and high ratios of Si to $\mathrm{N}$ and $\mathrm{P}$, most phytoplankton falls into the food spectrum of herbivorous, crustacean zooplankton in recent years (Sommer et al., 2002, 2008).

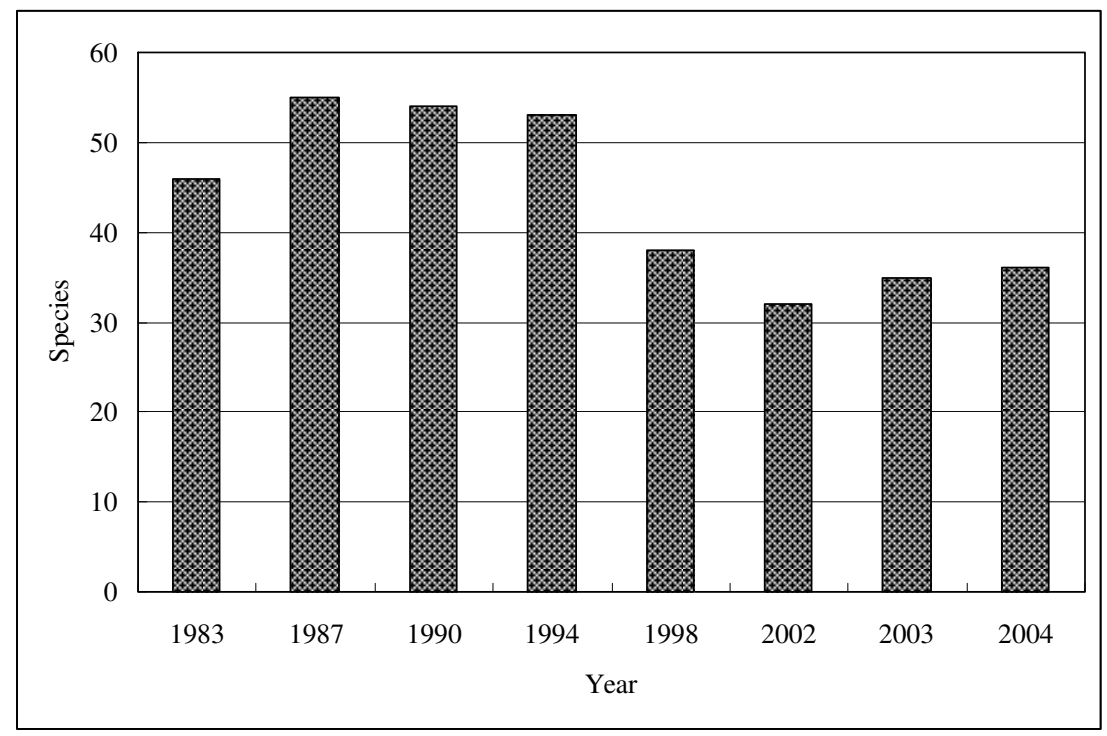

Fig. 14. Main species of the familiar zooplankton of Daya Bay changed from 1983 to 2004 (Wang et al., 2008).

Individual biomass changes of the zooplankton are shown in near the Nuclear power plant in Fig.15. Compared with the mean individual biomass of the zooplankton between 1982 to 1991 (from $392.25 \mathrm{ind} / \mathrm{m}^{3}$ to $680.75 \mathrm{ind} / \mathrm{m}^{3}$ ) before operation, it is very lower for $341 \mathrm{ind} / \mathrm{m}^{3}$ in 1994-1995 after the operation near the Nuclear power plant. The waste warm water is not good for zooplankton growth, especially in summer and autumn of each year. The waste warm water, which discharged to the south area of Daya Bay from the Nuclear Power Plants, directly impacts on zooplankton growth (Zheng et al., 2001).

A total of 328 species of fish were captured from 1985 to 2004, and 304 species of fishes were identified, including many edible species of high economic value such as Sardinella jussieu Clupanodon punctatus, Nematalosa nasus, Thrissa setirostris, Thrissa dussumieri, Thrissa kammalensis, Thrissa hamiltonii, Thrissa vitirostris, Harpodon nehereus, Plotosus anguillaris, Lactarius lactarius, Caranx (atule) kalla, Pseudosciaena arocea, Leioganthus rivulatus, Pagrosomus major, Rhabdosargus sarba, Siganus oramin, Trichiurus haumela, Stromateoides argenteus, Stromateoides nozawae, Stromateoides sinensis and Lagocephalus lunaris spsdiceus (Wang et al., 2008). The dominant species were perciformes including the warm-water and warm-andtemperate-water species accounted for about $90 \%$ and $10 \%$ in Daya Bay. The main fishes were about 20-28 species of 47 main species of fishes were captured in Daya Bay from 1985 to 2004 (Fig.16). Through the main species of fishes have a small change in Daya Bay from 
1985 to 2004, the amount of the edible fish natural resource has decreased greatly from 1985 to 2000 . The mean individual weight of the fish changed from $14.60 \mathrm{~g}^{\text {tail-1 }}{ }^{-1}$ in 1985 to $10.80 \mathrm{~g}$ tail- $^{-1}$ in 2004 (Table 4). Although a policy to ban-fishing in the China Sea was put in practice from July to August since 1995, the amount of the fish natural resource has recovered slowly because of excessive catching and pollution, speciealy in 1987-2000. The investigation data show that Daya Bay has a sandy bottom with coral reefs and an environment suitable for growth, the fish resources are abundant as compared to those in other bays in China that have less suitable environments. For example, there were only 91 species in Jiaozhou Bay in the temperate zone of China (Zhou, 1984).

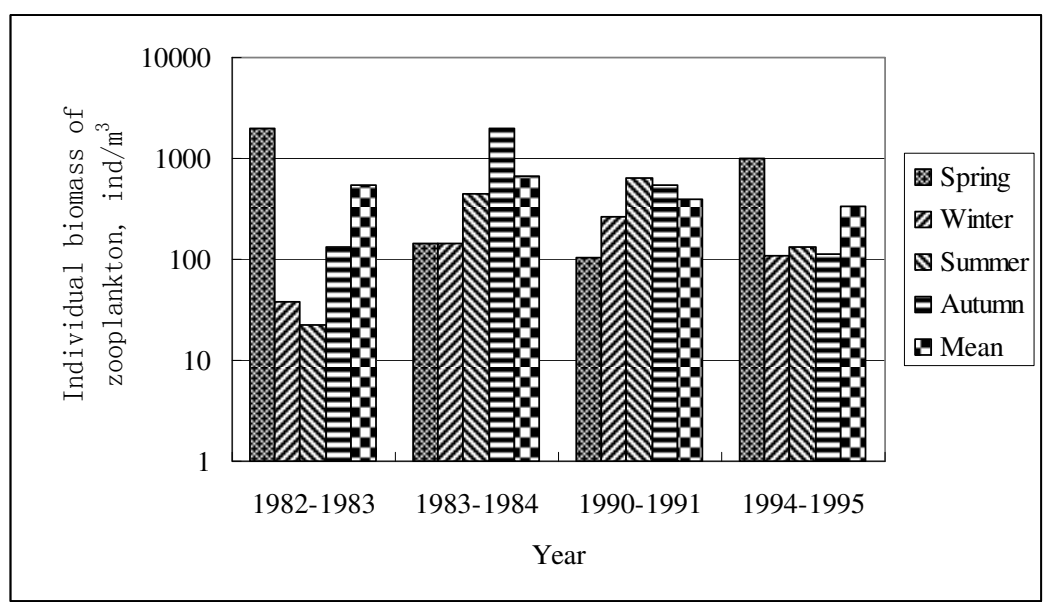

Fig. 15. Individual biomass changes of the zooplankton near the Nuclear power plant (ind $/ \mathrm{m}^{3}$ ).

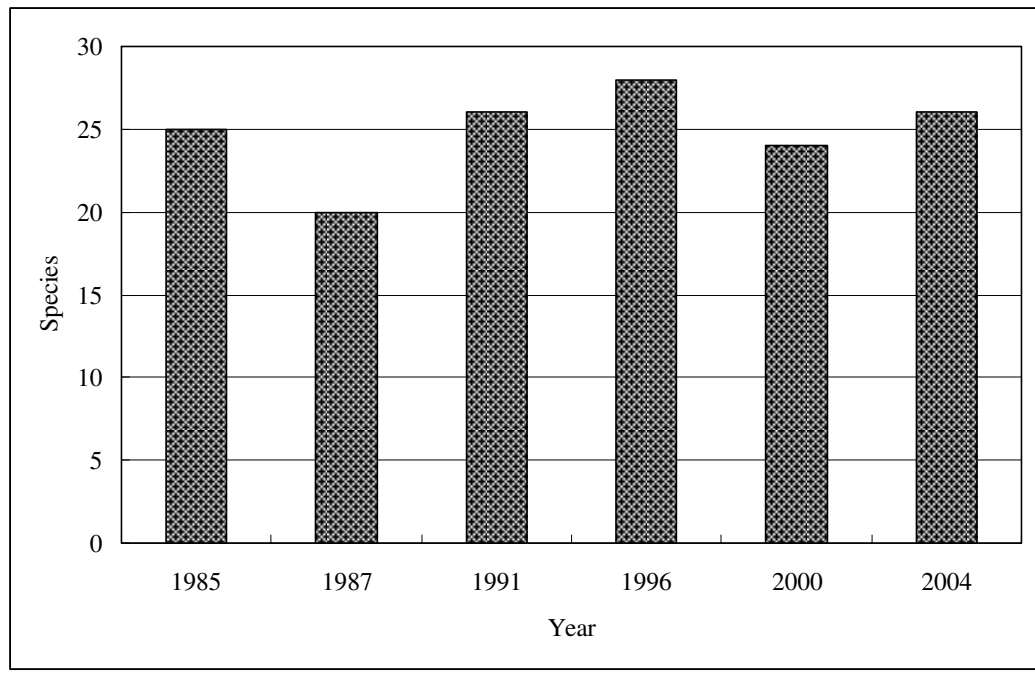

Fig. 16. Main species of fishes in Daya Bay from 1985 to 2004 (Wang et al., 2008) 
In order to evaluate the potential fishery production in the sea area around the Daya Bay Nuclear Power Plant before and after the operation, the potential fishery productions were $270 \mathrm{t} / \mathrm{a}$ in 1992-1993 (before the operation) and $550 \mathrm{t} / \mathrm{a}$ in 1994-1995 (after the operation) in $45 \mathrm{~km}^{2}$ sea area around the Daya Bay Nuclear Power Plant according to primary productivity and organic carbon of the phytoplankton (Peng et al., 2001).

\begin{tabular}{cccccc}
\hline Year & April & May & October & December & Mean \\
\hline 1985 & 9.70 & 6.30 & & 27.80 & 14.60 \\
1987 & 2.85 & 4.16 & & 1.92 & 2.98 \\
1996 & 1.08 & 2.51 & & 7.39 & 3.66 \\
2000 & & 2.28 & & & 2.28 \\
2004 & & & 10.80 & & 10.80 \\
\hline
\end{tabular}

Table 4. Mean individual weight of the fish ( $\mathrm{g}$ tail-1) changed from 1985 to 2004 (Wang et al., 2008).

Daya Bay has a high diversity of natural habitats, more than 700 species of benthos were found by mud sampling and trawling since 1982 (Xu, 1989; Wang et al., 2008, 2011). Bemthic plants were less than $10 \%$, including about 60 species of diatoms which were the main benthic plants. Benthic animals were more than $90 \%$. Besides a very few species, the benthic animals in Daya Bay were almost all warm-water species with relatively few individuals. The annual mean biomasses of benthic animals ranged from $55.70 \mathrm{~g} \mathrm{~m}^{-2}$ to $148.91 \mathrm{~g} \mathrm{~m}^{-2}$ ranging from 1982 to 2004 (Table 5). The lowest mean biomass of the benthic animal in Daya Bay was found to occur during 1990-1997, which was the largest foreign investment along the Daya Bay coast (Zang, 1993; Wang et al., 2006, 2008, 2011; Tang et al., 2003). The annual mean biomasses of benthic animals have increased from 1990 to 2004, and also reached the level of 1980s in recent years. The highest biomass of $1326 \mathrm{~g} \mathrm{~m}^{-2}$ was collected in north region of Daya Bay in spring of 1982. Polychaeta (about 150 species account for about 21\%) and molluscs (about 148 species account for about 21\%) were the dominant groups, followed by crustacea (about 130 species account for about 18\%) and echinoderms (about 52 species account for about 7\%), the rest (about 13\%, such as Spongia, Coelenterata, Bryozoa and Nemertinea etc.) exhibited the lowest biomass. 73 species of ground fishes (account for about 10\%) were captured in Daya Bay at 1982-2004. Seasonal variation of biomass showed similar trends with a maximum in winter and spring minimum in autumn or summer from 2001 to 2002 (Table 6). The maximum biomass in the year mainly occurred at the northeast and middle parts of Daya Bay, those were living areas of the mollusca $(\mathrm{Xu}, 1989$; Wang et al., 2008, 2011). The mean biomasses of benthic animals of western Daya Bay (near Nuclear Power Plants) have been decreasing from $317.7 \mathrm{~g} \mathrm{~m}^{-2}$ in 1991 to $45.24 \mathrm{~g} \mathrm{~m}^{-2}$ in 2004 (Table 7), and the number of benthic animal species was also decreasing since 1993 (Fig. 17). These results indicated that the warm water from the Daya Bay Nuclear Power Plant (since 1993) and Lingao Nuclear Power Plant (since 2002) had given great effects for this area ecology and environment, particularly for the benthos that was directly impacted marine organism (Zheng et al., 2001; Wang et al., 2008, 2011). 
Effects of the Operating Nuclear Power Plant

\begin{tabular}{llllllllll}
\hline Year & 1982 & 1987 & 1990 & 1996 & 1997 & 1998 & 2001 & 2002 & 2004 \\
\hline Biomass & $1.9-1326$ & $1.5-1210$ & $5.5-99$ & $0.1-1197$ & $0.4-823$ & $2-1122$ & $0-1236.6$ & $0-1152$ & $2.6-506.9$ \\
Mean & 123.1 & 123.6 & 55.70 & 74.20 & 78.60 & 152.80 & 148.91 & 117.71 & 126.68 \\
\hline
\end{tabular}

Table 5. Mean biomasses of benthic animals in Daya Bay from 1982 to 2004 (Wang et al., 2008) (Unit: $\mathrm{g} \mathrm{m}^{-2}$ ).

\begin{tabular}{ccccc}
\hline Year & Spring & Summer & Autumn & Winter \\
\hline 2001 & 256.18 & 88.05 & 47.10 & 248.77 \\
2002 & 96.11 & 14.11 & 64.98 & 279.53 \\
\hline
\end{tabular}

Table 6. Seasonal changed biomasses of benthic animals in Daya Bay changed from 2001 to 2002(Wang et al., 2008). (Unit: $\mathrm{g} \mathrm{m}^{-2}$ ).

\begin{tabular}{ccccccccccc}
\hline Year & 1991 & 1993 & 1994 & 1996 & 1996 & 1997 & 1998 & 2001 & 2002 & 2004 \\
\hline Biomass & $0.4-1651$ & $0.4-254.10 .1-120.80 .1-117.5$ & $0.1-158.0$ & $0.4-113.0$ & $4.4-1222$ & $0-197.7$ & $0-115.6$ & $20 . .6-76.6$ \\
Mean & 317.9 & 82.00 & 26.60 & 25.60 & 28.60 & 25.80 & 21.4 .3 & 34.15 & 28.84 & 45.24 \\
\hline
\end{tabular}

Table 7. Mean biomasses of benthic animals of western Daya Bay from 1991 to 2004(Wang et al., 2008) (Unit: $\mathrm{g} \mathrm{m}^{-2}$ ).

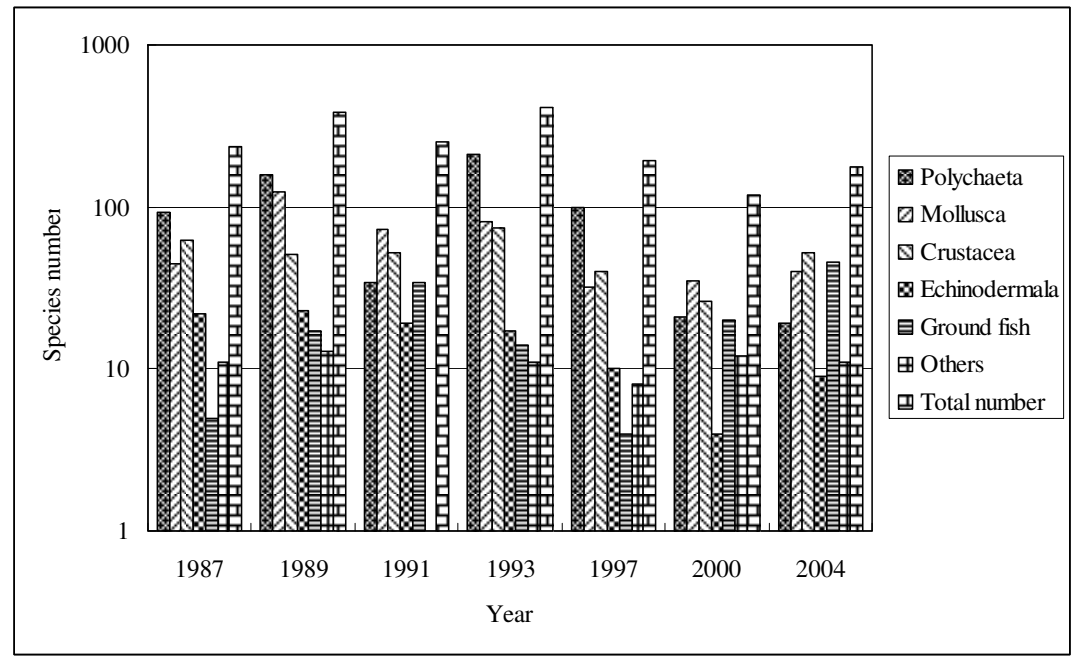

Fig. 17. Number of benthic animal species of western Daya Bay from 1987 to 2004 (Wang et al., 2008).

Coral reefs - the hermatypic coral are concentrated in the vicinity of Dalajia, Xiaolajia and west in the mouth of Daya Bay located at the northern edge of the global coral reef zone. Based on data collected in 1983-1984, there were formerly at least 19 coral species in Daya Bay (not included the part of Haotou harbour, which area was only investigated in 1964), accounting for $76.4 \%$ of the hermatypic coral from Dalajia and Xiaolajia to the mouth of the 
bay (Zhang \& Zhou, 1987), with Acropora pruinosa (Brook) as the dominant species. Only 12-16 species were found in 1991-2002, accounting for 32\% (Wen et al., 1996) and 36\% of total cover rate for the hermatypic coral (Table 8). There has been a shift in the dominated species since 1990s. For example the dominated species were Favites abdita (Ellis \& Solander) in 1991 and Platygyra daedalea (Ellis \& Solander) in 2002, which was $7.4 \%$ of the hermatypic coral for its total cover rate. The hermatypic coral were demolished from 1984 to 2002, some of which were destroyed by men (Wen et al., 1996; Souter \& Linden, 2000; Bellwood et al., 2004), such as bomb fishing, underwater coral reef sightseeing and exploitation of coral reef for making money. As one kind of sensitivity marine biology for water temperature, the coral bleaching is related to the going up of water temperature (Souter \& Linden, 2000). If the seawater temperature increases by $0.5-1.5^{\circ} \mathrm{C}$ in several weeks, about $90-95 \%$ coral will die (Zhang et al., 2001). The hermatypic coral of Daya Bay had a little recover from 1991 to 2002 (Wang et al., 2008). The increased temperature of Daya Bay being the global change and the warm water from the nuclear power plant may be also the other reasons for decreasing the cover rate of the hermatypic coral in Daya Bay (Zheng et al., 2001).

\begin{tabular}{cccc}
\hline Year & 1984 & 1991 & 2002 \\
\hline $\begin{array}{c}\text { Total species/total cover rate } \\
(\%)\end{array}$ & $19 / 76$ & $12 / 32$ & $16 / 36$ \\
\hline
\end{tabular}

Table 8. Investigation results of the hermatypic coral from 1984 to 2002 (Wang et al., 2008).

Mangrove plants grow along the coast of Daya Bay, such as in Aotou, Nianshan, Dongshan, Sanmen Island and Dalajia Island etc. There were 13 species belonged to 13 families (Chen et al., 1999; Zhong et al., 1999; Wang et al., 2008). There were some herbaceous and the ornamental vine in the mangrove plants of Daya Bay, such as Cyperusmalaccensis, Derristktrifoliata, Canavliamaritima, Ipomoeapescaprae, Plucheaindica, Sporobolusirginicus and Scavolahinanensis ect. The dominant species were Kandelia candel, Bruguiera gymnorrhiza, Aegiceras corniiculatum and Avicennia marina; and Ceriops tagal, Lumnitzera eacemosa, Rhizophora stylosa have gradually being deracinated (Chen et al., 1999). It now covers only $4 \%$ in some areas (such as in Baisha Bay of the northwest part in Daya Bay) as compared to $60-90 \%$ in 1950 s, which is mainly consisted of small shrubs and bushes. A great deal of mangrove plants was felled in order to create farmland in 1970s. The total mangrove plants are about $850 \mathrm{hm} 2$ along the Daya Bay coast at present. In recent years, the mangrove plants were again seriously destroyed and this phenomenon is accompanied with aquatic culture, the travel and economic development (Xue, 2002; Hens et al., 2000; Zoriniet al., 2004).

Obviously, the coral reefs-the hermatypic coral and mangrove plants in Daya Bay have seriously been degraded and destroyed since 1980s and 1970s. It will be need to make a much greater effort to protect these diverse resources to maintain their ecological functions (Wang et al., 2008).

\subsection{Identification of water quality and phytoplankton, benthos characteristics}

Water quality and phytoplankton data collected from 1999 to 2002 at 12 stations in Daya Bay are summarized in Table 9 (Wang et al., 2006). 


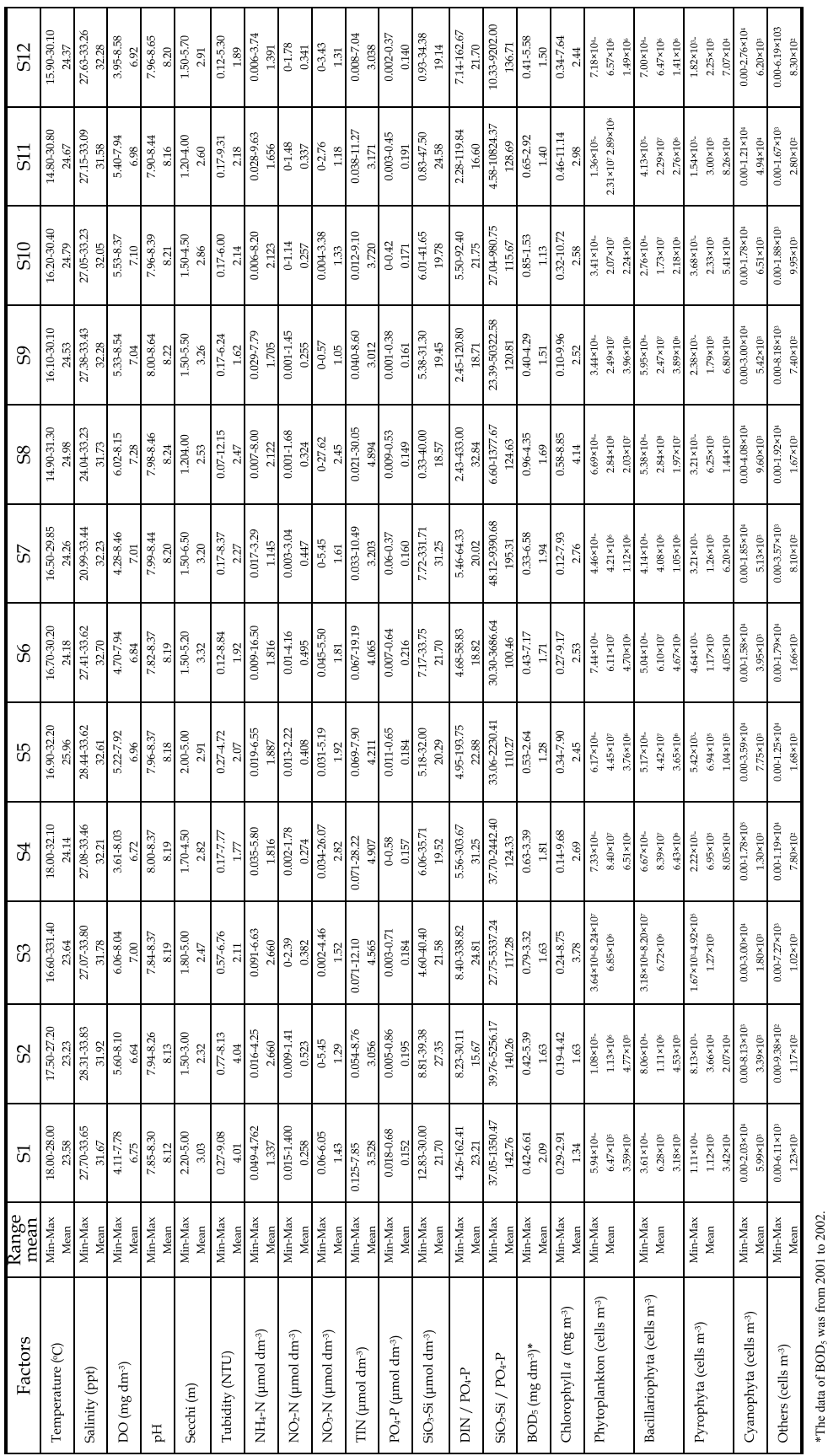

Table 9. Ranges and means of major physicochemical and biological factors in 12 stations in Daya Bay from 1999 to 2002 (Wang et al., 2006). 
Cluster analysis based on the major water quality parameters measured (first column Table 10) revealed that 12 monitoring stations could be grouped into three clusters. Flexible-Beta Cluster Analysis method was used and the corresponding dendrogram using FLExible-beta method between groups transforming measures with Flexible-Beta Distance is shown in Fig.18. Cluster I consisted of stations S1, S2, S7 and S11, in the south part of Daya Bay. Cluster II consisted of stations S5, S6, S9, S10 and S12, in the middle and northeast parts of Daya Bay. Cluster III consisted of stations S3, S4 and S8, in the cage culture areas of the southwest part of Daya Bay and the northwest part nearby the Aotou harbor of Daya Bay. By the FLExible-beta's method for cluster analysis, the results could also reflect there were the different function areas in the sea of Daya Bay (Wang et al., 2006).

Factor analysis techniques were used to investigate the various factors that present in each of three clusters identified by cluster analysis. Factors were identified by the principal component method with varimax rotation (using PROC X16 of the SAS system). Eigenvalues and cumulative proportions of correlation matrix are present in Table 10. In each cluster, more than $60 \%$ of the data variance could be explained by the first two principle components. In general, $\mathrm{pH}, \mathrm{NO}_{3}-\mathrm{N}$, TIN and TIN $/ \mathrm{PO}_{4}-\mathrm{P}$ are the most important factors in differentiating the characteristics of the three clusters as evident from the factor loadings. Cluster I with factor 1 (positive loadings for secchi, $\mathrm{NO}_{3}-\mathrm{N}, \mathrm{DIN}, \mathrm{TIN} / \mathrm{PO}_{4}-\mathrm{P}$ and $\mathrm{BOD}_{5}$ ) and factor 2 (positive loadings for temperature, $\mathrm{DO}, \mathrm{pH}$ and chlorophyll $a$ ) combined accounting for $32.61 \%$ of the data variance. Cluster II with factor 1 (positive loadings for $\mathrm{NO}_{2}-\mathrm{N}, \mathrm{NO}_{3}-\mathrm{N}, \mathrm{TIN}, \mathrm{PO}_{4}-\mathrm{P}, \mathrm{SiO}_{3}-\mathrm{Si}$, and Chlorophyll $a$ ) and factor 2 (positive loadings for tubidity, TIN/PO4-P and chlorophyll a) combined accounting for $25.31 \%$ of the data variance. Cluster III with factor 1 (positive loadings for temperature, $\mathrm{pH}$, secchi, NO3-N, TIN, TIN/PO4-P, SiO3-Si/PO4-P and BOD5) and factor 2 (positive loadings for DO, $\mathrm{pH}$, tubidity, NO2-N and chlorophyll a) combined accounting for $43.10 \%$ of the data variance (Wang et al., 2006).

Table 10 shows the corresponding factor loading in three clusters. It should be noted that NO3-N and TIN/PO4-P were important factors among stations in the three clusters, while concentrations of individual nutrient factors (i.e. NO2-N, NO3-N, TIN, PO4-P and SiO3-Si) were more important in Cluster II. These results were different to the research in Port Shelter, Hong Kong (Yung et al., 2001), which showed that nutrient ratios (i.e. TIN to TSi and $\mathrm{TP}$ to $\mathrm{TSi}$ ) were apparently the more important factors among stations in different clusters (Wang et al., 2006).

Water quality and benthos data collected from 2001 to 2004 at 12 stations in Daya Bay are summarized in Table11 (Wang et al., 2011).

Bivariate correlations between benthos biomass and major physical and nutrient factors were calculated for all stations. The density of benthos in all stations correlated positively with temperature, $\mathrm{DO}, \mathrm{pH}, \mathrm{NH}_{4}-\mathrm{N}, \mathrm{SiO}_{3}-\mathrm{Si}, \mathrm{SiO}_{3}-\mathrm{Si} / \mathrm{PO}_{4}-\mathrm{P}$, chlorophyll $a$ and negatively correlated with salinity, Secchi, COD, $\mathrm{NO}_{3}-\mathrm{N}, \mathrm{NO}_{2}-\mathrm{N}, \mathrm{TIN}, \mathrm{PO}_{4}-\mathrm{P}, \mathrm{TIN} / \mathrm{PO}_{4}-\mathrm{P}, \mathrm{BOD}_{5}$. Such relationship between nutrients and benthos was also found in the Lower Chesapeake Bay (Dauer \& Alden, 1995). The results of the correlation analysis revealed that not only temperature, $\mathrm{DO}, \mathrm{pH}, \mathrm{SiO}_{3}-\mathrm{Si}, \mathrm{SiO}_{3}-\mathrm{Si} / \mathrm{PO}_{4}-\mathrm{P}$, chlorophyll $a$, but also salinity, Secchi depth, $\mathrm{NO}_{3}-\mathrm{N}, \mathrm{NO}_{2}-\mathrm{N}$, TIN, TIN/PO $4-\mathrm{P}, \mathrm{BOD}_{5}$ could play an important role in determining the biomass of benthos in Daya Bay (Dauer \& Alden, 1995). The results are different from those using multivariate statistical analysis to study water quality and phytoplankton characteristics in Daya Bay from 1999 to 2002 (Wang et al., 2006). 


\begin{tabular}{|c|c|c|c|c|c|c|}
\hline & \multicolumn{2}{|l|}{ Cluster I } & \multicolumn{2}{|l|}{ Cluster II } & \multicolumn{2}{|c|}{ Cluster III } \\
\hline & F1 & $\mathrm{F} 2$ & F1 & F2 & F1 & F2 \\
\hline Temperature $\left({ }^{\circ} \mathrm{C}\right)$ & 0.01249 & 0.99037 & 0.16669 & 0.49016 & 0.87157 & 0.49027 \\
\hline Salinity (ppt) & 0.12846 & 0.02911 & 0.92371 & -0.30711 & 0.26872 & -0.96322 \\
\hline $\mathrm{DO}\left(\mathrm{mg} \mathrm{dm}^{-3}\right)$ & 0.19712 & 0.97137 & -0.85093 & 0.25263 & 0.15601 & 0.98775 \\
\hline $\mathrm{pH}$ & 0.07382 & 0.78155 & -0.90136 & -0.35794 & 0.62899 & 0.77741 \\
\hline Secchi (m) & 0.90952 & 0.33258 & 0.23706 & -0.94526 & 0.50374 & -0.86386 \\
\hline Tubidity (NTU) & 0.06313 & -0.98470 & 0.29705 & 0.88071 & 0.17229 & 0.98505 \\
\hline $\mathrm{NH}_{4}-\mathrm{N}\left(\mu \mathrm{mol} \mathrm{dm}{ }^{-3}\right)$ & -0.81998 & -0.57232 & -0.01719 & 0.28781 & -0.86639 & 0.49936 \\
\hline $\mathrm{NO}_{2}-\mathrm{N}\left(\mu \mathrm{mol} \mathrm{dm}{ }^{-3}\right)$ & -0.61670 & -0.18310 & 0.98970 & -0.09451 & -0.80358 & 0.59520 \\
\hline $\mathrm{NO}_{3}-\mathrm{N}\left(\mu \mathrm{mol} \mathrm{dm}{ }^{-3}\right)$ & 0.72416 & 0.01289 & 0.92253 & 0.26891 & 0.90624 & -0.42277 \\
\hline TIN $\left(\mu \mathrm{mol} \mathrm{dm}{ }^{-3}\right)$ & 0.87689 & -0.16412 & 0.73706 & 0.31524 & 0.98197 & -0.18905 \\
\hline $\mathrm{PO}_{4}-\mathrm{P}\left(\mu \mathrm{mol} \mathrm{dm}{ }^{-3}\right)$ & -0.99369 & 0.01984 & 0.73275 & -0.22751 & -0.99800 & -0.06318 \\
\hline $\mathrm{SiO}_{3}-\mathrm{Si}\left(\mu \mathrm{mol} \mathrm{dm}{ }^{-3}\right)$ & -0.19294 & 0.29027 & 0.81653 & -0.23589 & -0.98767 & -0.15652 \\
\hline $\mathrm{TIN} / \mathrm{PO}_{4}-\mathrm{P}$ & 0.98732 & -0.11482 & 0.03293 & 0.92628 & 0.99951 & 0.03141 \\
\hline $\mathrm{SiO}_{3}-\mathrm{Si} / \mathrm{PO}_{4}-\mathrm{P}$ & 0.45590 & 0.26096 & -0.60317 & 0.19426 & 0.99274 & -0.12029 \\
\hline $\mathrm{BOD}_{5}(\mathrm{mg} \mathrm{dm}-3)^{*}$ & 0.89595 & -0.36263 & 0.44634 & -0.75797 & 0.64454 & -0.76457 \\
\hline Chlorophyll $a\left(\mathrm{mg} \mathrm{m}^{-3}\right)$ & -0.23591 & 0.95703 & -0.33466 & -0.12719 & -0.12588 & 0.99205 \\
\hline $\begin{array}{l}\text { Cumulative \% of variance } \\
\text { explained }\end{array}$ & 39.40 & 32.61 & 42.60 & 25.33 & 56.90 & 43.10 \\
\hline
\end{tabular}

Table 10. Factor loadings (after varimax rotation) of first two factors for Cluster I, II and III (Wang et al., 2006).

Cluster analysis based on the major water quality parameters measured (first column Table 12) revealed that the 12 monitoring stations could be grouped into three clusters. Flexiblebeta cluster analysis method was used and the corresponding dendrogram using FLExiblebeta method between groups transforming measured with Flexible-beta distance, and the Flexible-beta cluster analysis result was shown in Fig.19. Cluster I consisted of the stations S1, S2, and S6 in the southern part of Daya Bay, where there are more effects from the Pearl River and South China Seas (Xu, 1989), such as the East Guangdong upwelling (Xu, 1989; Wang et al., 2006, 2008, 2011). Cluster II consisted of stations S3, S8 and S11 in the cage culture areas in the southwest part, the northwest part near the Aotou harbor and the northeast part near the Fenhe harbor of Daya Bay. The fish farming in Daya Bay has increased from an annual production of about 100 tons ( 440 ha cage culture area) in 1988 to approximately 60,000 tons $(\sim 14,000$ ha cage culture area) in 2005 , a nearly 600 -fold growth during the past 17 years (Wu et al., 2009b). Cluster III consisted of the stations S4, S5, S7, S9, S10 and S12 in the southwest, the middle and northeast parts of Daya Bay. The results of cluster analysis could also reflect the different functional areas of Daya Bay. These results are different from those reported for the water quality and phytoplankton characteristics in Daya Bay by Wang et al. (2006), and indicated also that human activities were the main factor impacting the ecological environment in Daya Bay (Wang, et al., 2008, 2011; Wu \& Wang, 2007; Wu et al., 2009, 2010). 


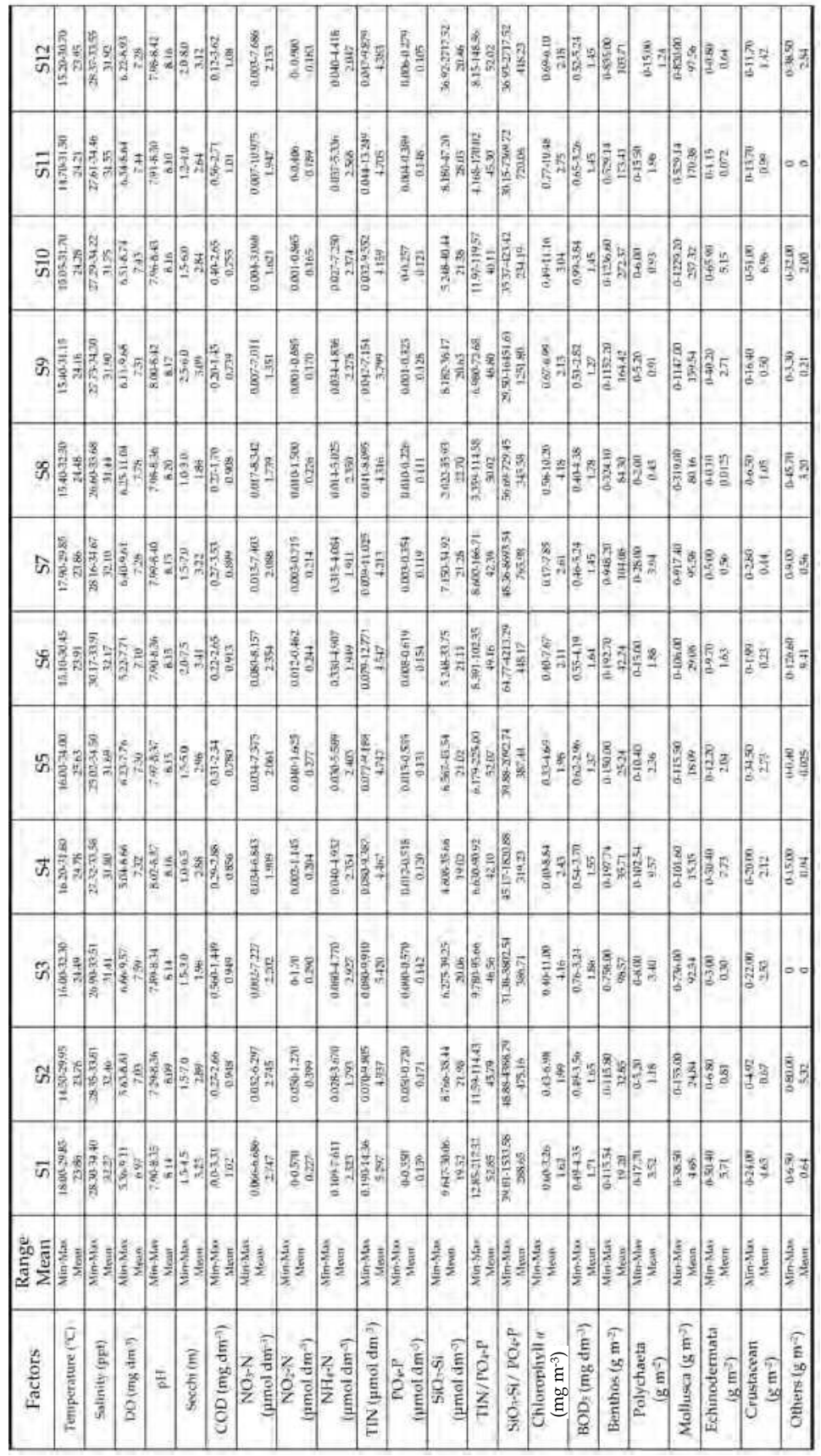

Table 11. Ranges and means of major physco-chemical and biological factors of 12 stations in Daya Bay from 2001 to 2004 (Wang et al., 2011). 


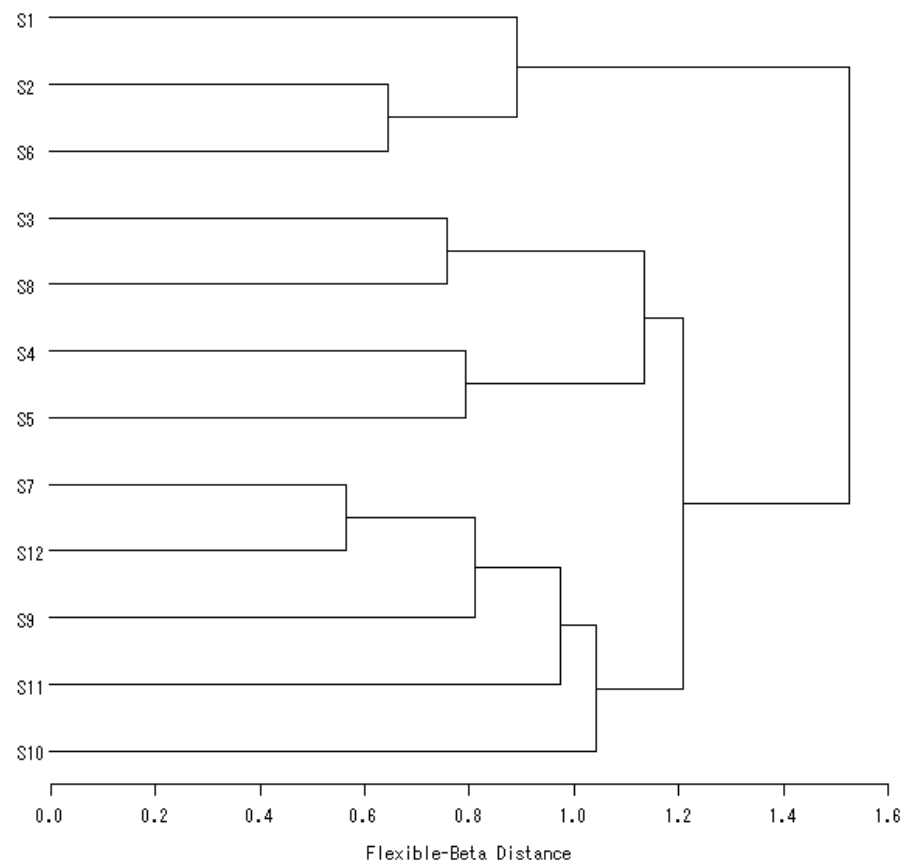

Fig. 19. Results of the FLExible-beta's method for cluster analysis showing the three clusters of all stations (Wang et al., 2011).

Factor analysis techniques were used to investigate the various factors that are present in each of three clusters identified by cluster analysis. Factors were identified by the principal component method with varimax rotation. Eigenvalues and cumulative proportions of correlation matrix are present in Table 12 (Wang et al., 2011).

In each cluster, more than $50 \%$ of the data variance could be explained by the first two principle components. In general, $\mathrm{NO}_{3}-\mathrm{N}, \mathrm{NH}_{4}-\mathrm{N}$ and TIN are the most important factors in differentiating the characteristics of the three clusters as evident from the factor loadings. Cluster I with factor 1 (positively with $\mathrm{COD}, \mathrm{NH}_{4}-\mathrm{N}, \mathrm{NO}_{3}-\mathrm{N}, \mathrm{TIN}, \mathrm{TIN} / \mathrm{PO}_{4}-\mathrm{P}$ and $\mathrm{BOD}_{5}$ ) and factor 2 (positively with temperature, $\mathrm{pH}$, Secchi and $\mathrm{NO}_{2}-\mathrm{N}$ ) accounted for $45.54 \%$ of the data variance. Cluster II with factor 1 (positively with $\mathrm{DO}, \mathrm{COD}, \mathrm{NO}_{3}-\mathrm{N}, \mathrm{BOD}_{5}$ and Chlorophyll $a$ ) and factor 2 (positively with $\mathrm{NH}_{4}-\mathrm{N}, \mathrm{NO}_{2}-\mathrm{N}, \mathrm{NO}_{3}-\mathrm{N}, \mathrm{TIN}, \mathrm{PO}_{4}-\mathrm{P}$ and $\mathrm{SiO}_{3}-$ $\mathrm{Si} / \mathrm{PO}_{4}-\mathrm{P}$ ) accounted for $38.36 \%$ of the data variance. Cluster III with factor 1 (positively with for $\mathrm{DO}, \mathrm{NO}_{3}-\mathrm{N}, \mathrm{TIN}, \mathrm{PO}_{4}-\mathrm{P}$ and $\mathrm{SiO}_{3}-\mathrm{Si}$ ) and factor 2 (positively with salinity, Secchi depth, $\mathrm{NO}_{3}-\mathrm{N}$ and $\mathrm{NO}_{2}-\mathrm{N}$ ) combined for $23.78 \%$ of the data variance.

Table 12 shows the corresponding factor loading in three clusters. It should be noted that $\mathrm{NO}_{3}-\mathrm{N}$ and $\mathrm{NH}_{4}-\mathrm{N}$ were important factors among stations in the three clusters, whereas concentrations of individual nutrient factors (i.e. $\mathrm{NH}_{4}-\mathrm{N}, \mathrm{NO}_{2}-\mathrm{N}, \mathrm{NO}_{3}-\mathrm{N}$, TIN and $\mathrm{PO}_{4}-\mathrm{P}$ ) were more important in Cluster II. These results were similar to the research for spatial characterization of nutrient dynamics in the Bay of Tunis (Souissi et al., 2000), for long-term changes in water quality and phytoplankton characteristics in Port Shelte (Yung et al., 2001) and also for the water quality and phytoplankton characteristics in Daya Bay (Wang et al., 
2006), which showed that the nutrients were apparently the more important factors among stations in different clusters)

\begin{tabular}{|c|c|c|c|c|c|c|}
\hline & \multicolumn{2}{|c|}{ Cluster I } & \multicolumn{2}{|c|}{ Cluster II } & \multicolumn{2}{|c|}{ Cluster III } \\
\hline & F1 & F2 & F1 & F2 & F1 & F2 \\
\hline Temperature $\left({ }^{\circ} \mathrm{C}\right)$ & -0.07402 & 0.99726 & -0.91594 & 0.17441 & 0.41463 & -0.84822 \\
\hline Salinity (ppt) & 0.08681 & -0.99622 & -0.86609 & -0.23685 & -0.79031 & 0.58854 \\
\hline $\mathrm{DO}\left(\mathrm{mg} \mathrm{dm}^{-3}\right)$ & -0.95422 & 0.29911 & 0.90756 & -0.23741 & 0.66559 & -0.56114 \\
\hline $\mathrm{pH}$ & 0.10302 & 0.99468 & 0.34421 & -0.88746 & -0.95259 & -0.18645 \\
\hline Secchi (m) & -0.08829 & 0.99609 & -0.97061 & -0.00703 & -0.81068 & 0.51100 \\
\hline $\operatorname{COD}\left(\mathrm{mg} \mathrm{dm}^{-3}\right)$ & 0.99806 & -0.06229 & 0.96300 & 0.13467 & 0.30587 & 0.37842 \\
\hline $\mathrm{NO}_{3}-\mathrm{N}\left(\mu \mathrm{mol} \mathrm{dm}{ }^{-3}\right)$ & 0.71192 & -0.70226 & -0.11188 & 0.98878 & 0.09577 & 0.63140 \\
\hline $\mathrm{NO}_{2}-\mathrm{N}\left(\mu \mathrm{mol} \mathrm{dm}{ }^{-3}\right)$ & -0.34213 & -0.93965 & 0.04398 & 0.88400 & 0.13031 & 0.98026 \\
\hline $\mathrm{NH}_{4}-\mathrm{N}\left(\mu \mathrm{mol} \mathrm{dm^{-3 } )}\right.$ & 0.85008 & 0.52665 & 0.50845 & 0.85305 & 0.73916 & -0.65671 \\
\hline $\operatorname{TIN}\left(\mu \mathrm{mol} \mathrm{dm}{ }^{-3}\right)$ & 0.96037 & -0.27873 & 0.24975 & 0.96593 & 0.69021 & 0.18550 \\
\hline $\mathrm{PO}_{4}-\mathrm{P}\left(\mu \mathrm{mol} \mathrm{dm} \mathrm{m}^{-3}\right)$ & -0.67938 & -0.73379 & -0.03668 & 0.99788 & 0.90839 & -0.09308 \\
\hline $\mathrm{SiO}_{3}-\mathrm{Si}\left(\mu \mathrm{mol} \mathrm{dm}{ }^{-3}\right)$ & -0.83054 & -0.55696 & 0.32481 & -0.39576 & 0.99190 & 0.01782 \\
\hline $\mathrm{TIN} / \mathrm{PO}_{4}-\mathrm{P}$ & 0.72370 & 0.69012 & -0.11296 & 0.06295 & -0.09709 & 0.01522 \\
\hline $\mathrm{SiO}_{3}-\mathrm{Si} / \mathrm{PO}_{4}-\mathrm{P}$ & -0.92164 & -0.38804 & -0.01222 & 0.79633 & 0.13335 & 0.24584 \\
\hline $\mathrm{BOD}_{5}\left(\mathrm{mg} \mathrm{dm}^{-3}\right)$ & 0.99133 & 0.13138 & 0.98990 & 0.09895 & 0.17930 & 0.25444 \\
\hline $\begin{array}{l}\text { Chlorophyll } a \text { (mg } \\
\mathrm{m}^{-3} \text { ) }\end{array}$ & -0.99963 & -0.02708 & 0.99220 & 0.02532 & 0.33479 & -0.16112 \\
\hline $\begin{array}{l}\text { Cumulative } \% \text { of } \\
\text { variance explained }\end{array}$ & 54.46 & 45.54 & 42.63 & 38.56 & 37.04 & 23.78 \\
\hline
\end{tabular}

Table 12. Factor loadings (after varimax rotation) of first two factors for Cluster I, II and III (Wang et al., 2011).

\section{Conclusions and suggestions in the future}

Daya Bay as a multi-type ecosystem including coral reef, mangrove and rock reef has a rich biodiversity. It is a good place for the reproduction and culturing of fish, shrimp, crabs and shellfish. Due to constant interaction between land and ocean area, its ecology is more complicated and vulnerable than that of the open seas. It is especially vulnerable to the effects of frequent human activities and land-based pollution. Depsite the progressive increases of human activities including more domestic sewage and industrial waste water discharged as well as nutrient enrichment and toxins derived from the cage culture of the fish and seashell, the concentrations of N, P, DO and COD must not be allowed to exceed water quality standards at the risk of serious ecosystem degradation and still were within the First Class of National Seawater Quality Standards for China. The temperatures of seawater in Daya Bay were increasing from 1982 to 2004 probably due to global change. The average ratio of N/P increased from 1.377 in 1985 to 49.09 in 2004, and the limiting factor of nutrients changed from $\mathrm{N}$ to $\mathrm{P}$. The composition of biological community has been small, with biodiversity simplified and the biological natural resource declined. For example, the species of phytoplankton decreased from 206 species of 56 genera in 1990 to 126 species of 44 genera in 2004, the waster warm water from the Nuclear Power Plant can provide extra amount of energy for phytoplankton growth (Wang et al., 2006); the main species of the zooplankton of Daya Bay had decreased from 46 species of 1983 to 36 species of 2004, the 
waste warm water is not a good environment for zooplankton growth, especially in summer and autumn of each year, which directly impacts on zooplankton growth (Zheng et al., 2001); the mean individual weight of the fish has changed from $14.8 \mathrm{~g}^{\text {tail-1 }} \mathrm{of}^{1985}$ to $10.80 \mathrm{~g}$ tail $^{-1}$ of 2004. Assessment for the potential fishery production between before and after the operation indicated that the potential fishery production after the operation was one time compared with before the operation in $45 \mathrm{~km}^{2}$ sea area around the Daya Bay Nuclear Power Plant (Peng et al., 2001). More than 700 species of benthos were found, the annual mean biomasses of benthic animals increased from $72.40 \mathrm{~g} \mathrm{~m}^{-2}$ in 1996 to $126.68 \mathrm{~g} \mathrm{~m}^{-2}$ in 2004 . The mean biomasses and species of benthic animals near the Nuclear Power Plants decreased from $317.9 \mathrm{~g} \mathrm{~m}^{-2}$ in 1991 to $45.24 \mathrm{~g} \mathrm{~m}^{-2}$ in 2004 and from 250 species in 1991 to 177 species in 2004 , the temperature value increased about $1^{\circ} \mathrm{C}$ compared with the other sea areas in Daya Bay (Wang et al., 2008). The waste warm water from the Nuclear Power Plants was the main factor influencing ecology and environment in the western area of Daya Bay, particularly for the benthos that directly impacted marine organism (Wang et al., 2008, 2011; Zheng et al., 2001). Many changes had taken place in Daya Bay from 1982 to 2004, such as stony coral bleaching, changed in dominate species of coral community, seriously degraded and destroyed mangrove plants. These results indicated that the ecosystem of Daya Bay is undergoing a rapid deterioration in some areas and in some aspects. At the same time, some aspects of its ecological environment were recovering due to strategic protection and management steps for protection and management of coastal marine ecosystems in China. For example, the annual mean biomasses of benthic animals increased from $72.40 \mathrm{~g} \mathrm{~m}^{-2}$ of 1996 to $1126.68 \mathrm{~g} \mathrm{~m}^{-2}$ of 2004 and the nutrient P decreased from 1985 to 2004. Daya Bay is a multi-type ecosystem mainly driven by human activities (Wang et al., 2006, 2008, 2011; Wu \& Wang, 2007).

The results of the present study indicated that the mean abundances of phytoplankton in all stations correlated positively with temperature, salinity, $\mathrm{DO}, \mathrm{pH}$, the ratio of TIN to $\mathrm{PO}_{4}-\mathrm{P}$, $\mathrm{NH}_{4}-\mathrm{N}, \mathrm{NO}_{3}-\mathrm{N}$, TIN and $\mathrm{PO}_{4}-\mathrm{P}$ and negatively correlated with secchi, tubidity, $\mathrm{SiO}_{3}-\mathrm{Si}$ to $\mathrm{PO}_{4}-\mathrm{P}$, and $\mathrm{SiO}_{3}-\mathrm{Si}$ and $\mathrm{NO}_{2}-\mathrm{N}$ by calculation with bivariate correlations. All stations could be groups into three clusters with Flexible-Beta Cluster Analysis method. Cluster I consisted of stations S1, S2, S7 and S11 in the south part and the northeast part of the Daya Bay. Cluster II consisted of stations S5, S6, S9, S10 and S12 in the middle and northeast parts of Daya Bay. Cluster III consisted of stations S3, S4 and S8 were in the cage culture areas in the southwest part of Daya Bay and in the northwest part near the Aotou harbor of the Daya Bay. The results also suggest that the nutrient and phytoplankton are good environmental indicators can rapidly image the changing water quality in Daya Bay, and this is the first attempt to analyze the water quality and phytoplankton characteristics in Daya Bay by multivariate statistics based on the investigated data in Daya Bay. The results of multivariate statistical analysis revealed that the temperature, dissolved oxygen, $\mathrm{NH}_{4}-\mathrm{N}$ and $\mathrm{NO}_{3}-\mathrm{N}$ could also play an important role in determining the density of phytoplankton in Daya Bay (Wang et al., 2006).

The results of the present study indicated that the biomass of benthos at all stations correlated positively with temperature, $\mathrm{DO}, \mathrm{pH}, \mathrm{NH}_{4}-\mathrm{N}, \mathrm{SiO} 3-\mathrm{Si}, \mathrm{SiO}_{3}-\mathrm{Si} / \mathrm{PO}_{4}-\mathrm{P}$ and chlorophyll $a$ and negatively correlated with salinity, Secchi depth, $\mathrm{COD}, \mathrm{NO}_{3}-\mathrm{N}_{2} \mathrm{NO}_{2}-\mathrm{N}$, TIN, $\mathrm{PO}_{4}-\mathrm{P}, \mathrm{TIN} / \mathrm{PO}_{4}-\mathrm{P}$ and $\mathrm{BOD}_{5}$ by calculation with bivariate correlations between benthos and major physical and nutrient factors. All stations could be grouped into three clusters. Cluster I consisted of stations S1, S2, and S6 were in the south part of Daya Bay. 
Cluster II consisted of stations S3, S4, S8 and S5 in the cage culture areas in the southwest part, the northwest part near the Aotou harbor and the northeast part near the Fenhe harbor of Daya Bay. Cluster III consisted of stations S7, S9, S10 S11 and S12 in the southwest, the middle and northeast parts of Daya Bay. The results also suggest that the nutrient and benthos are good environmental indicators that can rapidly image the changing water quality in Daya Bay. As a multi-type ecosystem Daya Bay seems to be mainly driven by human activities (Wang et al., 2008). The results revealed that temperature and nutrients could also play an important role in determining the biomass of benthos in Daya Bay (Wang et al., 2011).

The warm water from the Nuclear Power Plants and waste water from the cage culture areas had greatly influenced ecological processes and the environment in this region according to changes in biomass of benthos and water quality at different stations in Daya Bay (Wang et al., 2006, 2008, 2011). Particularly the benthos was directly impacted as marine organisms, thus there is a need for more research about waste warm water from the Nuclear Power Plants and from cage culture areas affecting the regional ecosystem of Daya Bay (Wang et al., 2006, 2008, 2011; Wu et al., 2009, 2010). Furthermore the development of fishfarming in Daya Bay should in future be controlled (Wu et al., 2009). According to the research of long-term changes of Daya Bay, regional coordination in protection and management of such vulnerable coastal marine ecosystems should be strengthened. The following strategic protection and management steps are recommended(Wang et al., 2008):

(i) Enhance information dissemination and education to improve environmental protection awareness for people in the region; (ii) Strengthen the long-term monitoring of the marine environment and coastal ecosystems in Daya Bay, enhance the research of regional environmental capacity, and use that capacity to establish large-scale control of pollutant discharges; (iii) Promote the protection of coral reefs, mangroves, coastal ecosystem and regional biodiversity by carrying out scientific plans for resource use based on marine system functions; (iv) Strictly enforce regulations relating to the marine environment and fisheries from June to August in each year; (v) More research about the waste warm water from the Nuclear Power Plants for effecting the ecosystem of Daya Bay should be carried out.

\section{Acknowledgements}

This research was supported by the project of knowledge innovation program of Chinese Academy of Sciences (No. KZCX2-YW-Q07-02, No. KSCX2-SW-132, KSCX2-SW-214), the National Natural Science Foundation of China (No. 41076070), the key projects in the National Science \& Technology Pillar Program in the Eleventh Five-year Plan Period (No. 2009BADB2B0606) and the National 908 project (No. 908-02-04-04).

\section{References}

Bellwood. D. R., Hughes. T.P., Folke, C. \& Nystrom, M., 2004. Confronting the coral reef crisis. Nature, 429, 827-833.

Bodergat, A.M., Oki, K., Ishizaki, K., and Rio, M., 2003. Impact of volcanism, human activities, and water mass circulation on the distribution of ostracod populations in Kagoshima Bay (Kyushu Island, southern Japan). Comptes Rendus Geosciences, 334(14), 1053-1059. 
Burger, J., 2003. Perceptions about environmental use and future restoration of an urban estuary. Journal of Environmental Planning and Management, 46(3), 399-416.

Buzzelli, C.P., 1998. Dynamic simulation of littoral zone habitats in lower Chesapeake Bay: ecosystem characterization related to model development. Estuaries, 21, 659-672.

Chen, H., Miao, S., Wang, H., and Xu, Y.M., 1999. A study on syn-ecology of mangrove at Daya Bay, China. Chinese Journal of Guangzhou Normal University, 20(2), 90-94.

Cloern, J.E., 1996. Phytoplankton bloom dynamics in coastal ecosystems: a review with some general lessons from sustained investigation of San Francisco Bay, California. Reviews of Geophysics, 34(2), 127-168.

Dauer, D.M., Alden, R.W., 1995. Long-term trends in the macrobenthos and water quality of the Lower Chesapeake Bay (1985-1991). Marine Polluton Bulletin 30(12): 840-850.

Fisher, T.R., 1991. Phytoplankton, nutrient and turbiding in the Chesapeake, Delaware and Hudson estuarine. Estuarine, Coastal and Shelf Science, 32, 187-206.

Han, W.Y., 1991. Carbon cycles of Daya Bay and the Preal River. Science Press, Beijing, China, p12-42.

Hansom, J.D., 2001. Coastal sensitivity to environmental change: a view from the beach. CATENA, 42(2), 291-305.

Hens, L., Nierynck, E., Van, Y T., Quyen, N.H., Hien, L.T.T., An, L.D., 2000. Land cover changes in the extended HA long city area, North-Eastern Vietnam during the period 1988-1998. Environment, Development and Sustainability, 2(3-4), 235-252.

Huang, L., Chen, Q., and Yuan, W., 1989. Characteristics of chlorophyll distribution and estimation of primary productivity in Daya Bay, China. Asian Marine Biology, 6, 115128.

Huang, L., Tan, Y., Song, X., Huang, X., Wang, H., Zhang, S., Dong, J., and Chen, R., 2003. The status of the ecological environment and a proposed protection strategy in Sanya Bay, Hainan Island, China. Marine Pollution Bulletin, 47(1-6), 180-186.

Johnson, R. A., Wichern, D. W., 1998. Applied multivariate statistical analysis. Prentice Hall, New York.

Justice, D., Rabalais, N.N., Turner, R.E., and Dortch, Q., 1995. Change in nutrient structure of river-dominated coastal waters: stoichiometric nutrient balance and its consequences. Estuarine, Coastal and Shelf Science, 40, 339-356.

Kerr R.A., 2010. Ocean acidification unprecedented, unsettling. Science, 328, 1500-1501.

Kont, A., Jaagus, J., Aunap, R., 2003. Climate change scenarios and the effect of sea-level rise for Estonia. Global and Planetary Change, 36(1), 1-15.

Lian, G.S., Lin, Y.H., Cai, B.J., Lin, M., Dai, Y.Y., and Lin, J.H., 1990. Characteristics of zooplankton community in Daya Bay. In: Third Institute of Oceanology, State Oceanic administration (eds), Collections of papers on marine ecology in the Daya Bay (II). China Ocean Press, Beijing, China, p274-281.

Lin, W.Q., and Li, S.Y., 2003. Three-D water quanity mathematical simulation of COD, DO, inorganic phosphorus and organic phosphorus in the Pearl River Estuary. Acta Oceanologica Sinica (in Chinese), 25(3), 129-137.

Mu, X.Y., Yang, Y.L., Li, C.Y., Yin, X.C., Jia, J.J., and Xue, Y.C., 1999. Eenvironmental characteristics of seawater in the Yuehu inlet Rongcheng Bay, China. Chinese Journal of Qingdao University, 14(4), 57-59.

Mumby, P. J., Edwards, A. J., Ernesto Arias-Gonzalez, J., Lindeman, K. C., Blackwell, P. G., Gall, A., Gorczynska, M. I., Harborne, A. R., Pescod, C. L., Renken, H., Wabnitz, C. 
C. C., Llewellyn, G., 2004. Mangroves enhance the biomass of coral reef fish communities in the Caribbean. Nature, 427, 533-536.

Olivieri, R.A., Chavez, F.P., 2000. A model of plankton dynamics for the coastal upwelling system of Monterey Bay, California. Deep-Sea Research II, 47, 1077-1106.

Pearson, H., 2005. Scientists seek action to fix Asia's ravaged ecosystems. Nature, 433, 94.

Peng, Y.H , Chen, H.R.,Pan, M.X., Huang, H.H.,Gao, H.L.2001. The primary production and potential fishery production in the sea area around the Daya Bay Nuclear Power Station before and after the operation of DBNPS. Journal of Fisheries China (in Chinese), 25 (2), 161-165.

Shen, Z.-L., 2001. Historical changes in nutrient structure and its influences on phytoplantkon composition in Jiaozhou Bay. Estuarine, Coastal and Shelf Science, 52, 211-224.

Sohma, A., Sekiguchi, Y., Yamada, H., Sato, T., and Nakata, K., 2001. A new coastal Marine ecosystem model study coupled with hydrodynamics and tidal flat ecosystem effect. Marine Pollution Bulletin, 43(7-12), 187-208.

Sommer, U., Stibor, H., Katechakis, A., Sommer, F., Hansen, T., 2002. Pelagic food web configurations at different levels of nutrient richness and their implications for the ratio fish production: primary production. Hydrobiologia, 484(1-3), 11-20.

Sommer, U., Lengfellner, K., 2008. Climate change and the timing, magnitude, and composition of the phytoplankton spring bloom. Global Change Biology, 14(6), 11991208.

Souissi, S., Daly Yahia-Kéfi, O., 2000. Spatial characterization of nutrient dynamics in the Bay of Tunis (south-western Mediterranean) using multivariate analyses: consequences for phyto- and zooplankton distribution. Journal of Plankton Research 22(11), 2039-2059.

Souter, D.W., and Linden, O., 2000. The health and future of coral reef systems. Ocean and Coastal Management, 43(8), 657-688.

Tagliani, P.R.A., Landazuri, H., Reis, E.G., Tagliani, C,R., Asmus ML, Sanchez-Arcilla A., 2003. Integrated coastal zone management in the Patos Lagoon estuary: perspectives in context of developing country. Ocean and Coastal Management, 46(9), 807-822.

Tang, D.L., Kester, D.R., Wang, Z.D., Lian, J.S., Kawamura, H., 2003. AVHRR satellite remote sensing and shipboard measurements of the thermal plume from the Daya Bay, nuclear power station, China. Remote Sensing of Environment, 84, 506-515.

Turner, R.E., Rabalais, N.N., 1994. Coastal eutrophication near the Mississippi River delta. Nature, 368, 619-621.

Wang, Y. S., Wang, Z.D., Huang, L.M., 2003. Changes in the ecological environment of Daya Bay and the trends in recent 20 years, [in:] Chinese Ecosystem Research Network (CERN), Center of Chinese Ecosystem Research Network (eds.), Proc. 11th Chinese Ecosystem Research Network, Sanya, China, 606-614.

Wang, Y.S., Xu, J.R., Dong, J.D., Jiang, H.C., 2004. Ecological environment characteristics of thermocline and its kinetic mechanism in Daya Bay. In: Center of Chinese Ecosystem Research Network (eds), Collections of chinese ecosystem research. Proc 12th Chinese Ecosystem Research Network, Changsha, China, p 226-231. 
Wang, Y.S., Lou, Z.P., Sun, C.C., Wu, M.L., Han, S.H., 2006. Multivariate statistical analysis of water quality and phytoplankton characteristics in Daya Bay, China, from 1999 to 2002. Oceanologia, 48 (2), 193-211.

Wang, Y.S., Lou, Z.P., Sun, C.C., Sun, S., 2008. Ecological environment changes in Daya Bay, China, from 1982 to 2004. Marine Pollution Bulletin. 56(11), 1871-1879.

Wang Y.S., Sun C.C., Lou Z.P. et al. Identification of water quality and benthos characteristics in Daya Bay, China, from 2001 to 2004. Oceanological and Hydrobiological Studies, 2011, 40(1), 82-95.

Wei G. F., Wang Z. D., Lian J. S., 2003. Succession of the dominant phytoplankton species in spring 2000 in at Dapeng'Ao cove, Daya Bay. Acta Ecologica Sinica (in Chinese), 32(11), 2285-2296.

Wen, W.Y., Zou, R.L., Du, W.C., Huang, X.P., Zheng, Q.H., Zhang, G.X., Liang, Z.Q., Li, T.S., 1996. Impacts of warm effluent from the Dayawan nuclear power plant on stony coral community I. Stony community before the operation of the nuclear power plant. In: Pian, J.P., Cai, G.X. (eds), Annual research reports of MBRS(I). Science Press, Beijing, China, p18-22.

Wu, M.L., Wang, Y.S., 2007. Using chemometrics to evaluate anthropogenic effects in Daya Bay, China. Estuarine, Coastal and Shelf Science, 72, 732-742.

Wu, M.L., Wang, Y.S., Sun, C.C., Wang, H., Lou, Z.P., Dong, J.D., 2009a. Identification of water quality by using chemometrics in Daya Bay, China, Oceanologia 51 (2), 217232.

Wu, M.L., Wang, Y.S., Sun, C.C., Wang, H., Dong, J.D., Han, S.H., 2009b, Identification of anthropogenic effects and seasonality on water quality in Daya Bay, South China Sea, Journal of Environmental Management, 90, 3082-3090.

Wu, M.L., Wang, Y.S., Sun, C.C., Wang, H., Dong, J.D., Yin, J.P., Han, S.H., 2010. Identification of coastal water quality by statistical analysis methods in Daya Bay, South China Sea. Marine Pollution Bulletin, 60, 852-860.

Xue, C., 2002. The impact of human activities on mangrove coast of Kosrae Island, the federated states of Micronesia. Transaction of Oceanology and Limnology (in Chinese), 2, 17-23

Xu, G.Z., 1989. Environments and resources of Daya Bay. Anhui Scienctific and Technical Publishers, HeFei, China, p 8-9, 10-16.

Yanez-Arancibia, A., Lara-Dominguez, A.L., Rojas Galaviz, J.L., Zarate Lomeli, D.J., Villalobos Zapata, G.J, Sanchez-Gil, P., 1999. Integrating science and management on coastal marine protected areas in the Southern Gulf of Mexico. Ocean $\mathcal{E}$ Coastal Management, 42,319-344.

Yang, Q.L., 1990. Ecologic characteristics of phytoplankton community in Daya Bay. In: Third Institute of Oceanology, State Oceanic administration (eds), Collections of papers on marine ecology in the Daya Bay (II). China Ocean Press, Beijing, China, p 266-273.

Yin, K., Qian, P.Y., Wu, M.C.S., Chen, J.C., Huang, L., Song, X., Jian, W.J., 2001. Shift from P to $\mathrm{N}$ limitation of phytoplankton biomass across the Pearl River Estuarine plume during summer. Marine Ecological Progress Series, 201, 65-79.

Yin K., 2003. Influence of monsoons and oceanographic processes on red tides in Hong Kong waters. Marine Ecology Progress Series, 262, 27-41. 
Yung, Y. K., Wong, C.K., Yau, K., Qian, P.Y., 2001. Long-term Changes in Water Quality and Phytoplankton Characteristics in Port Shelter, Hong Kong, from 1988-1998. Marine Pollution Bulletin, 42(10), 981-992.

Zang, M.C., 1993. Nuclear power programs in China. Atomwirtschaft-Atometechnik (in German), 38(6), 419-420.

Zhao, S.J., Jiao, N.Z., Wu C.W., Liang, B., Zhang, S.Y., 2005. Evolution of nutrient structure and phytoplankton composition in the Jiaozhou Bay ecosystem. Chinese Joumal of Environmental Sciences, 17(1), 95-102.

Zheng, Q.H., He, Y.Q., Zhang, G.X., 2001. Impacting on the ecological environment and marine organism by waster water discharged to the sea in Daya Bay. In Pian, J.P., Wang, Z.D., Wu, X.Z. (eds), Annual research reports of MBRS (III): Science Press, Beijing, China, p10-15.

Zhang, Q.M., 2001. Status of tropical biological coasts of China: implications on ecosystem restoration and resconstruction. Ocenaologia and Limnologia Sinica (in Chinese), 32(4), 454-464.

Zhang, Y.L., Zhou, R.L., 1987. Community structure of shallow water stony corals in Daya Bay. Chinese Journal of Tropical Oceanography, 6(1), 12-18.

Zhong, Z.X., Huang, Y.Y., Zhang, H.D., 1999. Research on primary productivity quantitative parameters and structure of mangrove community in Daya Bay of Guangdong Province. Scientia Silvae Sinicae, 35(2), 26-30.

Zorini, L.O., Contini, C., Jiddawi, N., Ochiewo, J., Shunula, J., Cannicci, S., 2004. Participatory appraisal for potential community-based mangrove management in East Africa. Wetlands Ecology and Management, 12(2), 8 7-102

Zhou, J.K., 1984. Factor analysis of the distributive relationship of the fish numbers in the Jiaozhou Bay. Marine Science Bulletin (in Chinese), 3(3), 58-67. 


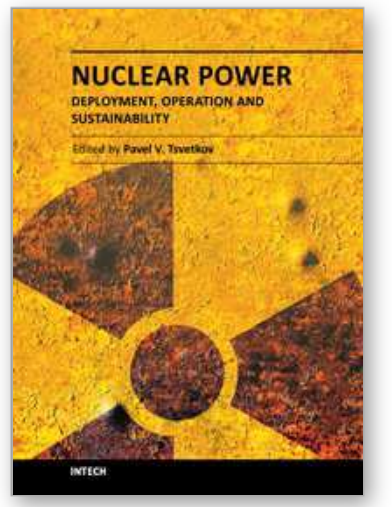

\author{
Nuclear Power - Deployment, Operation and Sustainability \\ Edited by Dr. Pavel Tsvetkov
}

ISBN 978-953-307-474-0

Hard cover, 510 pages

Publisher InTech

Published online 09, September, 2011

Published in print edition September, 2011

We are fortunate to live in incredibly exciting and incredibly challenging time. Energy demands due to economic growth and increasing population must be satisfied in a sustainable manner assuring inherent safety, efficiency and no or minimized environmental impact. These considerations are among the reasons that lead to serious interest in deploying nuclear power as a sustainable energy source. At the same time, catastrophic earthquake and tsunami events in Japan resulted in the nuclear accident that forced us to rethink our approach to nuclear safety, design requirements and facilitated growing interests in advanced nuclear energy systems. This book is one in a series of books on nuclear power published by InTech. It consists of six major sections housing twenty chapters on topics from the key subject areas pertinent to successful development, deployment and operation of nuclear power systems worldwide. The book targets everyone as its potential readership groups - students, researchers and practitioners - who are interested to learn about nuclear power.

\title{
How to reference
}

In order to correctly reference this scholarly work, feel free to copy and paste the following:

You-Shao Wang (2011). Effects of the Operating Nuclear Power Plant on Marine Ecology and Environment - A Case Study of Daya Bay in China, Nuclear Power - Deployment, Operation and Sustainability, Dr. Pavel Tsvetkov (Ed.), ISBN: 978-953-307-474-0, InTech, Available from: http://www.intechopen.com/books/nuclearpower-deployment-operation-and-sustainability/effects-of-the-operating-nuclear-power-plant-on-marineecology-and-environment-a-case-study-of-daya-

\section{INTECH}

open science | open minds

\section{InTech Europe}

University Campus STeP Ri

Slavka Krautzeka 83/A

51000 Rijeka, Croatia

Phone: +385 (51) 770447

Fax: +385 (51) 686166

www.intechopen.com

\section{InTech China}

Unit 405, Office Block, Hotel Equatorial Shanghai

No.65, Yan An Road (West), Shanghai, 200040, China 中国上海市延安西路65号上海国际贵都大饭店办公楼 405 单元

Phone: +86-21-62489820

Fax: +86-21-62489821 
(C) 2011 The Author(s). Licensee IntechOpen. This chapter is distributed under the terms of the Creative Commons Attribution-NonCommercialShareAlike-3.0 License, which permits use, distribution and reproduction for non-commercial purposes, provided the original is properly cited and derivative works building on this content are distributed under the same license. 